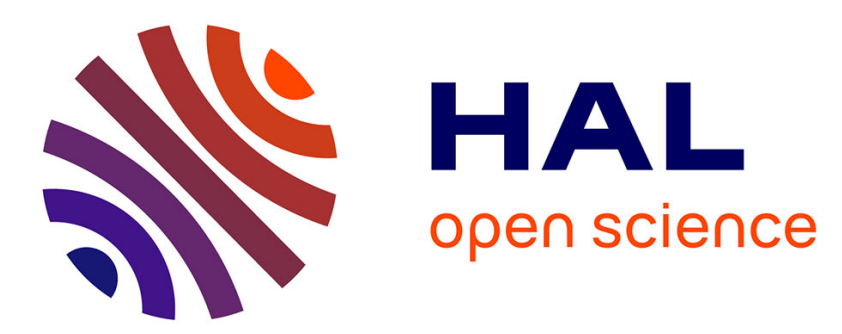

\title{
Characterization of Barley Straw, Hemp Shiv and Corn Cob as Resources for Bioaggregate Based Building Materials
}

Aurélie Laborel-Préneron, Camille Magniont, Jean-Emmanuel Aubert

\section{To cite this version:}

Aurélie Laborel-Préneron, Camille Magniont, Jean-Emmanuel Aubert. Characterization of Barley Straw, Hemp Shiv and Corn Cob as Resources for Bioaggregate Based Building Materials. Waste and Biomass Valorization, 2018, 9 (7), pp.1095 - 1112. 10.1007/s12649-017-9895-z . hal-01876843

\section{HAL Id: hal-01876843 https://hal.science/hal-01876843}

Submitted on 18 Sep 2018

HAL is a multi-disciplinary open access archive for the deposit and dissemination of scientific research documents, whether they are published or not. The documents may come from teaching and research institutions in France or abroad, or from public or private research centers.
L'archive ouverte pluridisciplinaire HAL, est destinée au dépôt et à la diffusion de documents scientifiques de niveau recherche, publiés ou non, émanant des établissements d'enseignement et de recherche français ou étrangers, des laboratoires publics ou privés. 

bioaggregate based building materials

3

4

Aurélie Laborel-Préneron ${ }^{\mathrm{a}}$, Camille Magniont ${ }^{\mathrm{a}}$, Jean-Emmanuel Aubert ${ }^{\mathrm{a}}$

5 a LMDC, Université de Toulouse, INSA/UPS Génie Civil, 135 Avenue de Rangueil, 31077

6 Toulouse cedex 04 France.

*Corresponding author: Aurélie Laborel-Préneron

Tel. +33 (0)5 61559926 Fax: 0033 (0)5 615599 49;

e-mail: alaborel@insa-toulouse.fr

\section{ABSTRACT}

Expanding the use of low-environmental impact materials in the field of building materials is a major aim in a context of sustainable development. These alternative materials should be non-polluting, eventually recycled, and locally available. Bioresources are already used in some building materials but few studies have investigated their relevance in such applications. The aim of this paper is to evaluate the suitability of three kinds of vegetal aggregates: barley straw, hemp shiv and corn cob. The availability of these bioresources, extracted from a French database, is discussed, as are their physical properties and chemical compositions. Their microstructure is described with SEM images and their particle size distributions are provided through image analysis. Sorption-desorption isotherms are measured by a Dynamic Vapour Sorption system. Bulk density, thermal conductivity and water absorption are also quantified. The results highlight a tubular structure for the three different aggregates, with low bulk density and thermal conductivity $(0.044,0.051$ and 0.096 $\mathrm{W} . \mathrm{m}^{-1} \cdot \mathrm{K}^{-1}$ respectively for straw, hemp shiv and corn cob) and high water absorption, especially for barley straw and hemp shiv (414 and 380\% vs. 123\% for corn cob). Their hygric regulation capacity is also sufficiently good, with a water sorption of between 20 and $26 \%$ at $95 \%$ of relative humidity. These plant aggregates could therefore be used as additions in an earth matrix, or a hydraulic, pozzolanic, air lime or gypsum binder, or just as loose-fill insulation material. However, future research should focus on their resistance to fire and bacterial growth to validate this approach.

Keywords: Barley straw, hemp shiv, corn cob, bio-based building material, availability, 
37 The impacts of buildings on environment, and especially on energy consumption and $\mathrm{CO}_{2}$ emissions have now become priority issues. Energy use in buildings generates about $40 \%$ of the EU's total final energy consumption and $36 \%$ of its $\mathrm{CO}_{2}$ emissions [1]. Innovation or changes are thus necessary to decrease buildings' environmental impact and improve their energy efficiency. Currently, in France, a huge proportion of non-renewable materials is used in the construction industry and large amounts of waste are produced (around 50 million tons per year, while municipal solid waste is around 30 million tons per year [2]). On the way to a sustainable future, eco-friendly building materials could be part of the solution. These materials would allow consumption and pollution to be reduced during the production process and also during their whole service life and their end-of-life. In that context, bio-based building materials present the advantage of using plant resources that have absorbed $\mathrm{CO}_{2}$ through photosynthesis and can thus reduce the material's environmental impact by sequestering $\mathrm{CO}_{2}$ for at least the life-time of the construction [3]. Bio-sourced materials and the building sector have been identified by the French Ministry of Ecology, Sustainable Development and Energy (Commissioner-General for Sustainable Development) as one of the 18 "green" sectors with a high potential for economic development in the future. In order to produce these low carbon materials, renewable resources, such as by-products from agriculture or forests, are needed. An example that is being increasingly studied is a bio-based earth material. Unfired earth bricks are fibred with distinct renewable resources such as kenaf fibre [4], straw [5], wood chips [6] or wool fibre [7]. Plant concretes, which combine bioaggregates with a pozzolanic, lime-based or cement matrix, are also a good alternative. Numerous studies on hemp concrete currently exist [811] and there are also some concerning sunflower [12] or lavender [13] concrete. Although bio-resources are renewable, they also need to be cultivated at locations close to where they are implemented so as to avoid unnecessary transportation and its related environmental impacts. For that reason, the present paper focuses on estimating the potential availability of such resources in the case of France, where by-products and the availability of agricultural land are increasingly being studied, especially with a view to the use of bio-fuels [14-16]. However, these studies provide information about quantities of available, still-unused byproducts which could be employed as building materials. A similar study has already been carried out by Palumbo et al. [17] for insulating materials. Their study focused on the main resources available in Europe and especially in Spain, i.e. cereals and sunflower. Biomass is more and more in demand. In the past, it was already used but population growth engendered an increase in food needs. Studies are now being conducted to avoid biomass usage conflicts between priority sectors and others. The former concern human 
(biomaterials, bio-based chemistry) and energy, which are considered as lower priority by France Agrimer [18]. This study will focus only on plant-sourced biomass. Plant particle characteristics, which are very specific to the raw material, are studied and compared in the present paper. These characteristics have to be taken into account in the development and the characterization of further composite materials. Three plant aggregates were studied in this work because they were readily available and presented important morphological differences: barley straw, hemp shiv and corn cob. Straw is currently one of the most commonly studied plant aggregates, and is the subject of one third of the 50 references reviewed by Laborel-Préneron et al. [19]. This resource, very common in the plant world, is also present in our cultural heritage [20], [21]. It can come from wheat [22-24], barley [22], [25], oats [26] or other cereals. Hemp shiv constitutes a resource that has received considerable attention in France, which is the greatest producer of hemp in Europe with more than $50 \%$ of the total European production [27]. This plant aggregate is especially studied for use in hemp concrete [28], [29] but also as a bio-composite material with earth [30], [31]. Corn cob is an original resource that has been studied only once with an earth matrix, but not crushed [32]. It was studied by Verdier et al. in a pozzolanic matrix [33], and corn pith, which is softer, was studied by Palumbo as an insulating material in an alginate matrix [34].

The use of bio-based aggregates in building materials is becoming increasingly widespread. It is worth noting that various plant aggregates are available in the world and could be used for building construction. However at the present time, no international standardized method exists for characterizing such materials, as it already exists for mineral aggregates. The new standard could define testing protocols for the characterization of bio-aggregates and also the restrictions applying to each application in building materials. This lack of recognized procedures led the RILEM BBM Technical Committee to work on recommendations concerning protocols for bio-aggregate characterization, mainly on hemp shiv [35]. Applying these recommendations to other plant aggregates is a way to check the validity of the method. The objective of this study is thus to characterize and observe the differences of three available agro-resources by following the RILEM recommendations in terms of bulk density, thermal conductivity, water absorption and particle size analysis. Complementary characteristics proposed by other authors are also studied: availability in France, microscopic description, chemical composition and sorption-desorption capacity. This whole methodology could allow the differences between the characteristics of these three plant particles to be highlighted and their potential for future applications in building materials to be assessed.

\section{MATERIALS AND METHODS}

109 
Straw is an agricultural by-product and is the part of cereal stems rejected during the harvest. Barley is harvested once or twice a year. It is the third most cultivated cereal in France with 10 million tons per year [18]. The straw studied here (Fig.1), already chopped, was supplied by the CalyClay company (Drôme, France), which is specialized in services for straw and earth construction.

\subsubsection{Hemp shiv}

France was the first producer of hemp in 2013 [36]. Hemp shiv is the by-product of the hemp defibration process and corresponds to the lignin-rich part of the stem (Fig.1). It was provided by the Agrofibre company in Cazères (Haute-Garonne, France).

\subsubsection{Corn cob}

Maize is the second most cultivated cereal in France, with around 15 million tons per year [18]. Corn cob is the central part of the ear of maize, cleared of grain and crushed. The "woody" part (in red in Fig.1), which is also the hardest part, was studied here. This corn cob, already calibrated, was provided by the Eurocob company in Maubourguet (HautesPyrénées, France).

126
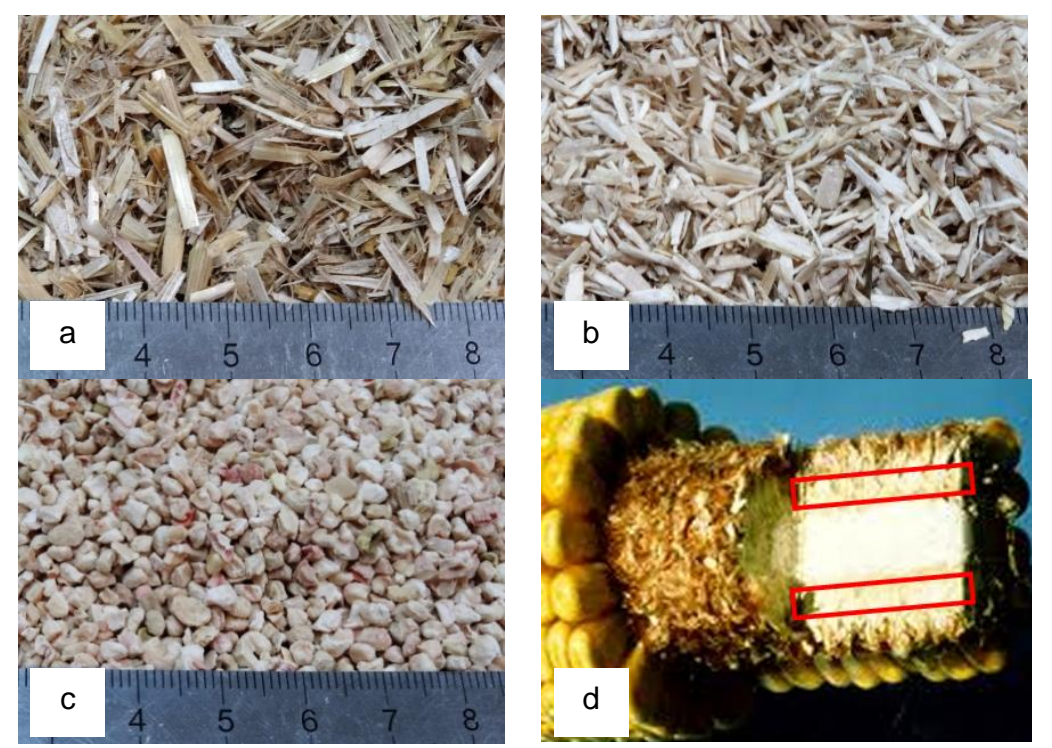

Fig.1 Raw materials (a) Barley straw, (b) Hemp shiv, (c) Corn cob and (d) Part of corn 128 studied (in red)

The availability of resources was estimated for the case of metropolitan France and specifically for biomass from agriculture, the agri-food sector, industrial crops and forestry residues. Most data providing both the yearly total and the available production of crop byproducts come from a national authority, France Agrimer [18], which monitors products and

134 biomass from agriculture and the sea. The data presented in this study are from 2015 and 
135 some values were completed by data from 2013-2014 in Agreste [37], provided by the 136 French Ministère de l'Agriculture, de l'Agroalimentaire et de la Forêt. In these two references, 137 data were collected from various economic bodies such as Ademe (Agence de 138 l'Environnement et de la Maîtrise de l'Energie), IGN (Institut National de I'Information 139 Géographique et Forestière) and the FAO (Food and Agriculture Organization of the United 140 Nations). Nevertheless, the collected information should be interpreted cautiously, as a 141 resource may not have been fully counted.

142 Some data, specifically for industrial crops, were expressed only as quantity produced, and 143 were therefore converted into quantity available by applying the unused biomass factor found 144 in Jölli and Giljum [38]. Furthermore, data corresponding to forestry biomass were given by 145 volume per year $\left(\mathrm{Mm}^{3} / \mathrm{y}\right)$. In order to be compared with the other resources, volume was 146 converted into mass assuming a density of $0.88 \mathrm{t} / \mathrm{m}^{3}$, which is an average for various wood 147 species from an FCBA memento [39]. No recent data were available concerning fruit 148 production, except for those for wine and cider production. Agri-food industry by-products will 149 be thus slightly undervalued.

150

151 Twenty-four distinct resources were documented in these two references (France Agrimer 152 and Agreste), such as soft wheat, sunflower and beetroot. It was decided to group them into 1535 families: cereals, oilseed crops, industrial crops, agri-food industry residues and wood 154 residues.

155 The method for determining the available by-products $(\mathrm{Ba})$ was based on the following 156 equation 1, greatly inspired by the work of Palumbo et al. [17]

$$
B a=B t-B n-B u
$$

157 where $\mathrm{Bt}$ is the total by-products $(\mathrm{Mt} / \mathrm{y}), \mathrm{Bn}$ is the non-harvestable by-products (Mt/y) 158 (necessary to maintain soil fertility or inaccessible) and Bu corresponds to by-products 159 allocated for other uses (Mt/y) such as litter, animal feed or energy (only in the case of 160 wood). All quantities of by-products were expressed by mass (dry basis) over one year and 161 they were determined from areas and farm yield. This equation is recapitulated by Fig. 2 . 
162

163

164

165

166

167

168

169

170

171

172

173

174

175

176

177

178

179

180

181

182

183

184

185

186

187

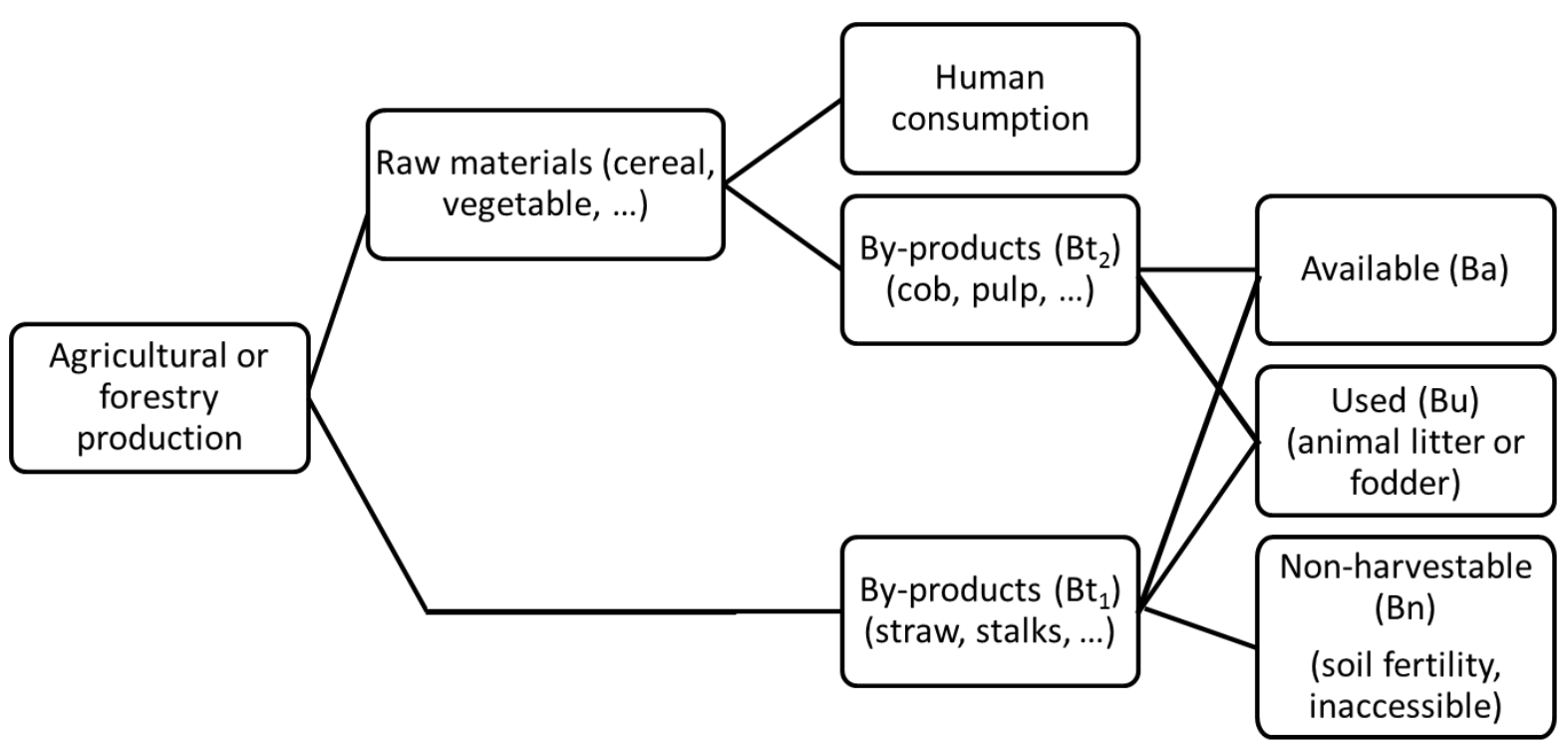

Fig.2 Recapitulative scheme of utilization of by-products

For example, for oleaginous plants, it was considered that the minimum return to the soil to maintain agronomic potential was $50 \%$ of the straw produced [18].

\subsection{Physical properties of plant aggregates}

Most of the physical plant aggregate characterization tests were based on a current work of the RILEM TC 236-BBM because there is no standardized method for this kind of material. To evaluate the validity of the results and analyse the dispersion of the results, these protocols recommend calculating a coefficient of variation. This coefficient corresponds to the ratio between the standard deviation and the mean value. The mean value is considered to be representative if the coefficient is lower than $5 \%$. The methods are explained in the following sections.

\subsubsection{Microscopic description (SEM images)}

Porous structure and morphology were analysed visually with a JEOL - JSM-6380 LV Scanning Electron Microscope (SEM). The particles were glued onto a metallic support and then covered with a thin layer of evaporated gold before observation. These microstructural investigations were carried out with a $15 \mathrm{kV}$ accelerating voltage in high vacuum mode.

\subsubsection{Particle size analysis}

A particle size analysis was performed by image analysis using ImageJ software. This increasingly used method [40-42] is particularly interesting in the case of non-spherical particles. Size distribution and morphology (width and length) were determined using this method whereas traditional mechanical sieving analysis would have given only the width. However, this method is only achievable for small quantities of particles. 
First, the particles were sieved at $500 \mu \mathrm{m}$ to remove dust. The plant aggregates were then

189

190

191

192

193

194

195

196

197

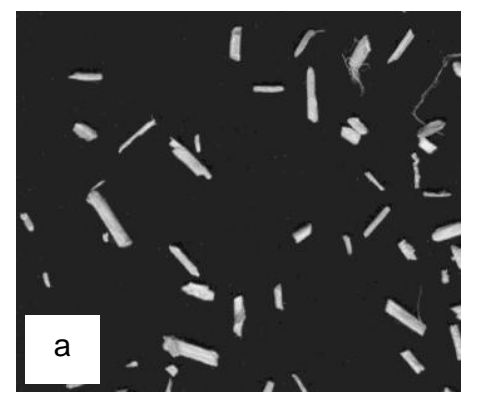

198

199

200

201

202

203

204

205

206

207

208

209

210

211

212

213

214

215 of the results.

\subsubsection{Bulk density}

homogenized before being distributed into small boxes. The particles were scanned on a black background in order to obtain better contrast for the ImageJ analysis (Fig.3). All the particles were then grouped into a single table to plot representative curves. In total, more than 7000 particles were analysed for each type of plant aggregate which corresponds to a mass of $6.7 \mathrm{~g}$ of straw, $13.6 \mathrm{~g}$ of hemp shiv or $71.0 \mathrm{~g}$ of corn cob. This is more than the mass recommended by the RILEM TC 236-BBM, of between 3 and $6 \mathrm{~g}$, or the minimum number of 1000 particles suggested by [43]. Sampling quality is a key point for the representativeness

Fig.3 Particle image processing of straw: (a) Scan in shades of grey, (b) Image processing

This analysis gave the geometrical parameters of the particles: the major and minor axis lengths (Major and Minor respectively), and the Equivalent Area Diameter (EAD), based on a particle of circular cross section and calculated with equation 2 :

$$
E A D=\sqrt{\frac{4 * A}{\pi}}
$$

with A the cross sectional area of the particle $\left(\mathrm{m}^{2}\right)$. It also gave the aspect ratio (AR) which is the length to width ratio, or Major to Minor ratio. If the value is close to 1 , the particle is almost circular or square; the more AR differs from 1, the more elongated is the particle.

Three specimens of each plant aggregate were dried at $60^{\circ} \mathrm{C}$ until the weight became constant (weight variation of less than $0.1 \%$ between two weighings $24 \mathrm{~h}$ apart). Each specimen was put in a cylindrical mould $12 \mathrm{~cm}$ in diameter and $24 \mathrm{~cm}$ high. The mould dimensions were chosen in accordance with the RILEM work. The RILEM TC observed that the mould size used to measure bulk density had very little effect on the density as long as the height was at least twice the diameter and the diameter was at least $10 \mathrm{~cm}$ (big enough compared to the particle size). The quantity of material was selected by a quartering procedure and adjusted to be half the volume of the mould. The mould was then upended 10 times before the final level was marked with a cardboard disk. The volume occupied by the 
particles was measured from the weight of the corresponding volume of water and the bulk

217 density $\left(\rho_{b}, \mathrm{~kg} \cdot \mathrm{m}^{-3}\right)$ was calculated using equation 3 :

$$
\rho_{b}=\frac{m_{d}}{m_{w}} \times \rho_{w}
$$

218 where $m_{d}$ is the mass of dry particles $(\mathrm{kg}), \mathrm{m}_{\mathrm{w}}$ is the mass of water $(\mathrm{kg})$ and $\rho_{w}$ is the density 219 of water $\left(1000 \mathrm{~kg} \cdot \mathrm{m}^{-3}\right)$.

220 The bulk density of a given type of plant aggregate was taken as the average value 221 measured on three samples.

\subsubsection{Thermal conductivity}

224

where $Q$ is the heat input $(W), e_{t}$ the total thickness $(m)$ and $S$ the cross section of the specimen $\left(\mathrm{m}^{2}\right)$. Knowing the dimensions and thermal conductivity of the PVC box, the thermal conductivities of the plant aggregates were then deduced. A transfer by conductivity through the plant aggregates and the box was assumed. Three specimens of each plant aggregate were dried at $60^{\circ} \mathrm{C}$ until the weight became constant (weight variation less than $0.1 \%$ between two weighings $24 \mathrm{~h}$ apart). The particles were put in a PVC box of dimensions $15 \times 15 \times 5 \mathrm{~cm}^{3}$, thermal conductivity $0.11934 \mathrm{~W} \cdot \mathrm{m}^{-1} \cdot \mathrm{K}^{-1}$ and thickness $1.6 \mathrm{~mm}$. According to the recommendations of the RILEM TC 236-BBM, the dry density of the sample for thermal conductivity measurement was checked and adjusted (by shaking) to the same value measured during the bulk density test. For this last test, the procedure recommends upending the cylindrical mold ten times. The measurements were made with a hot plate apparatus ( $\lambda$-meter EP 500) and were performed at $25^{\circ} \mathrm{C}$. The specimen was located between the two plates of the apparatus, one hot and the other one cold, with a temperature difference of $\Delta T=10 \mathrm{~K}$. A steady state was assumed to have been reached when the change in conductivity was less than $1 \%$ in 60 minutes. The apparent thermal conductivity of the plant aggregates within the PVC box $\left(\lambda_{\text {app }}\right.$ in $\left.\mathrm{W} \cdot \mathrm{m}^{-1} \cdot \mathrm{K}^{-1}\right)$ was calculated at the steady state with the following equation:

$$
\lambda_{\text {app }}=\frac{Q \cdot e_{t}}{\Delta T \cdot S}
$$

The specimens were weighed at the end of the test to measure the water uptake during the measurement.

\subsubsection{Water absorption}

Water absorption during 1 minute, 15 minutes, 4 hours and 48 hours was measured on 3 specimens of each of the 3 plant aggregates. Each sample was dried at $60^{\circ} \mathrm{C}$ until the weight became constant (weight variation less than $0.1 \%$ between two weighings $24 \mathrm{~h}$ apart). 
mass, of $25 \mathrm{~g}$ for straw, $20 \mathrm{~g}$ for hemp shiv and $50 \mathrm{~g}$ for corn cob, depended on the available volume of the nets. It is assumed that representativeness was ensured by careful mixing and quartering the particles. After water immersion, the samples were drained for 1 minute in their nets with a salad spinner and then weighed to determine their water absorption (\%) according to the following equation:

$$
w(t)=\frac{m(t)-m_{0}}{m_{0}} \times 100
$$

254 255

256

257

258

259

260

261

262

263

264

265

266

267

268

269

270

271

272

273

274

275

276

277

278

279

where $\mathrm{m}(\mathrm{t})$ is the wet mass after spinning $(\mathrm{kg})$ and $\mathrm{m}_{0}$ is the dry mass $(\mathrm{kg})$.

\subsection{Chemical characterization}

Before the tests, samples were crushed to a grain size of less than $1 \mathrm{~mm}$ and dried at $105^{\circ} \mathrm{C}$ for at least $12 \mathrm{~h}$. The main chemical compounds were measured by the Eurofins company using the Van Soest method, according to standard NF V18-122 [44]. This test provides 3 results: NDF (Neutral Detergent Fibre), corresponding to the total fibre; ADF (Acid Detergent Fibre), which contains mainly cellulose and lignin; and ADL (Acid Detergent Lignin), corresponding to the lignin. Measurement uncertainties were $10 \%$ for NDF and ADF and $15 \%$ for ADL. Cellulose and hemicellulose were thus calculated by the subtractions ADFADL and NDF-ADF, respectively.

The following two tests were carried out in triplicate in the laboratory. To determine the proportion of water-soluble components, around $1 \mathrm{~g}$ of dried material $\left(\mathrm{m}_{\mathrm{i}}, \mathrm{kg}\right)$ and $100 \mathrm{~mL}$ of distilled water were introduced into a flask and boiled for $1 \mathrm{~h}$ in a heating system with return flow. The mixture was then separated by filtration on a sintered-glass filter. The flask and the filter containing the sample were dried at $105^{\circ} \mathrm{C}$ and weighed to obtain the mass of aggregates after boiling $\left(m_{f}, k g\right)$ by deducting the tare weights $t_{1}$ (flask) and $t_{2}$ (filter). The water-soluble content (WS) was determined according to equation 6:

$$
W S(\%)=\frac{m_{i}-m_{f}}{m_{i}} \times 100
$$

To determine the mineral matter content, around $1 \mathrm{~g}$ of dried material $\left(\mathrm{m}_{\mathrm{i}}\right)$ was heated at $550^{\circ} \mathrm{C}$ for $7 \mathrm{~h}$ in a crucible of tare weight $\mathrm{t}$. After cooling in a desiccator, the ash was weighed in the crucible $\left(\mathrm{m}_{\mathrm{f}}\right)$. Mineral matter content $(\mathrm{MM})$ was calculated with equation 7 :

$$
M M(\%)=\frac{m_{f}-t}{m_{i}} \times 100
$$

The coefficients of variation were between 10 and $18 \%$ and between 2 and $8 \%$ for extractive and ash contents respectively.

\subsection{Sorption-desorption isotherms}


280 The sorption-desorption property is necessary to model the buffering effect of a material and 281 has great influence on its resistance to the proliferation of micro-organisms [34]. The 282 sorption-desorption isotherms of the 3 plant aggregates were evaluated by the Dynamic 283 Vapour Sorption (DVS) method. Temperature and relative humidity were regulated by the 284 device (Surface Measurement Systems, London, UK). The uncertainties of the device are \pm $2850.01 \mathrm{mg}$ for the microbalance, $\pm 0.2^{\circ} \mathrm{C}$ for the PT100 thermometer and $\pm 0.5 \%$ for the dew 286 point sensor. The specimen, suspended by a micro-balance, was weighed every 60 seconds. 287 Two specimens of each plant aggregate were tested and were assumed to be representative 288 of these very hygroscopic materials [45-47]. The mass of the samples tested was very low, 289 between 13 and $65 \mathrm{mg}$, due to the volume available in the sample holder. The samples were 290 composed of 10 to 20 plant particles. However, Bui et al. [47] have shown that a sample of $29120 \mathrm{mg}$ of cut straw shows quite a good representativeness on DVS measurements. Before 292 testing, the specimen was dried for $2 \mathrm{~h}$ at $50^{\circ} \mathrm{C}$ (using dry $\mathrm{N}_{2}$ gas) in the DVS device. The 293 test was carried out at $23^{\circ} \mathrm{C}$, which is the temperature specified in the standard for the 294 saturated salt solution method, NF EN ISO 12571 [48]. Relative humidity was regulated in 295 successive stages from 0 to $95 \%$ by steps of $10 \%$, except for the last stage, which was equal 296 to $5 \%$. For each step, the specimen was considered to have reached moisture balance if $297 \mathrm{dm} / \mathrm{dt}<5.10^{-5} \% \cdot \mathrm{min}^{-1}$ over a ten-minute period [49] or in a maximum time interval of 360 298 minutes (twice this time for the last three steps). Fig.4 shows an example of straw sorption299 desorption behaviour with this programme. It can be seen that, at high relative humidity, the 300 change of step was triggered by the time criterion, which resulted in a slight underestimation 301 of the moisture content for the last three steps. 


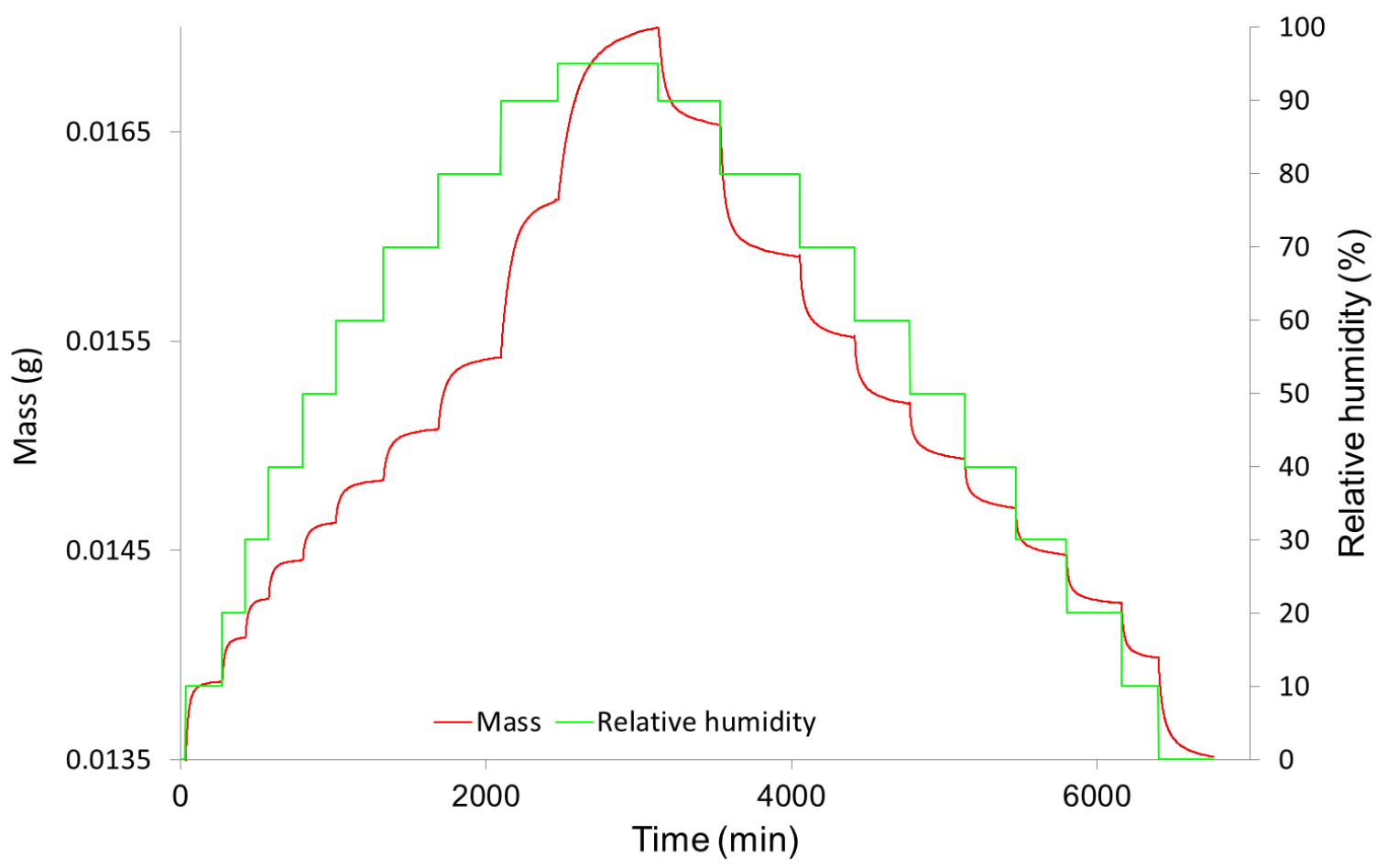

Fig.4 Typical variation of mass and relative humidity for the DVS (here sorption-desorption of 304 barley straw)

\section{RESULTS AND DISCUSSION}

307 Fig.5 represents the quantities of by-product produced $(\mathrm{Bt})$ and available $(\mathrm{Ba})$ for the 5 308 families mentioned in the Material and Methods section. Production is greatest for the cereal 309 straw family with $85 \mathrm{Mt} / \mathrm{y}$, while the most available by-product is wood residue with $33 \mathrm{Mt} / \mathrm{y}$. 310 Nevertheless, the availability of cereal straw is $7 \mathrm{Mt} / \mathrm{y}$.

311 The families of the three plant particles of the present study are framed in orange: barley 312 straw, hemp shiv and corn cob, belonging respectively to cereal straws, industrial crops and 313 agri-food industry by-products. 


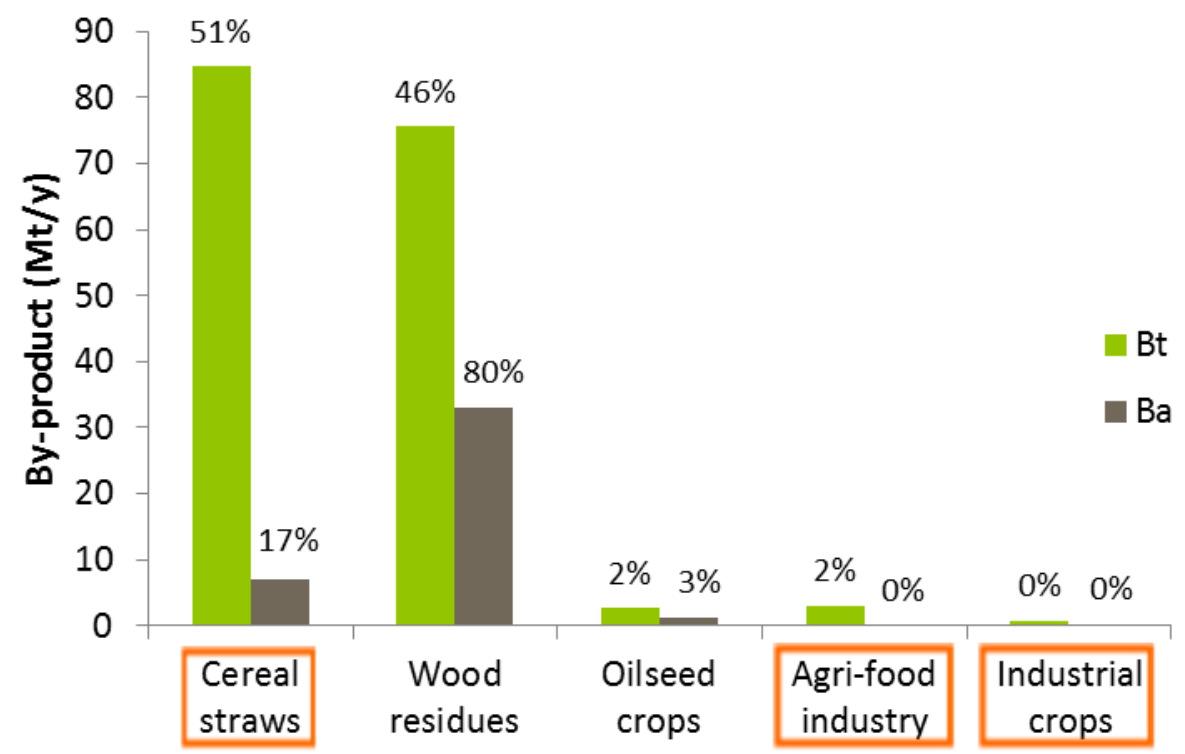

315 Fig.5 Production and availability of different by-product families

316 The quantities of by-products produced are represented in Fig. 6 for the 3 families 317 (agricultural crops, agri-food industry and industrial crops). Production is presented rather 318 than availability, because available resources are not reported by France Agrimer [18] or 319 others for the agri-food industry and industrial by-products. The majority of agri-food industry 320 by-products are used for animal fodder.

321 Cereal straw and stalks and oleaginous crops are included in agricultural crops. Barley straw 322 makes up the second highest quantity produced in this category and the third most available 323 crop by-product, with 4.3 Mt/y, after soft wheat straw and maize stalk. Much more cereal 324 straw is produced than oleaginous straw (rape, sunflower and soya).

325 Corn cob is a by-product of the agri-food industry. It is included in corn by-product, along with 326 leaf and damaged grain. The quantity of corn by-product produced is around $0.24 \mathrm{Mt} / \mathrm{y}$, 327 which makes it the fourth category produced in this family.

328 Hemp is the second most-produced industrial crop by-product after flax, with around 17 329 thousand tons. This value is much lower than those of the other plant aggregates selected, 330 but it is a plant by-product that has already been the subject of a number of studies for 331 building materials. France is the biggest European hemp producer [27], and some 332 professional rules exist [50]. This has led to the development of construction or rehabilitation 333 of buildings with hemp concrete in the past 10 years. 

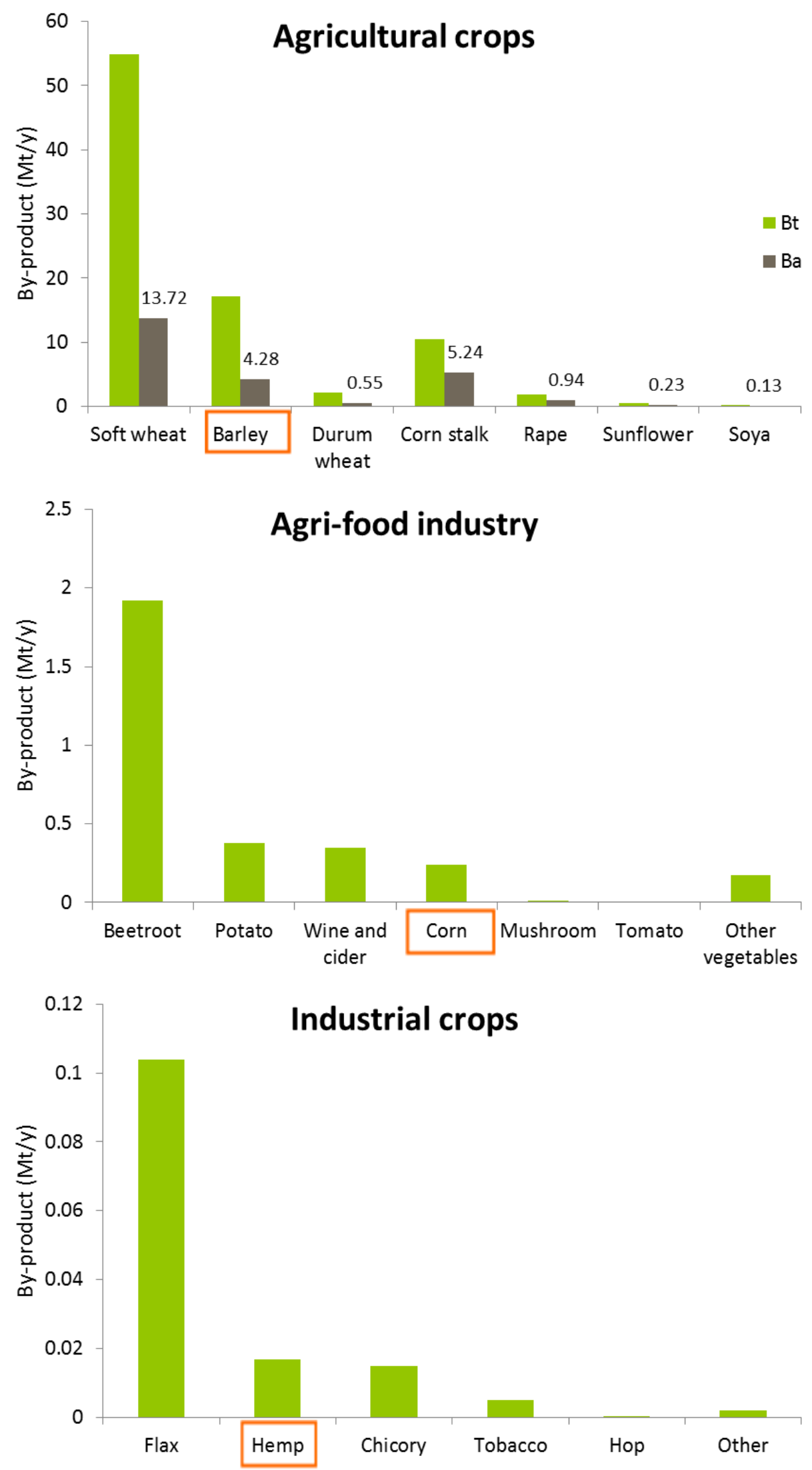

334 Fig.6 Quantities of by-products from agricultural crops, agri-food industry and industrial crops 
In France, various types of by-products are available, in different proportions. Cereal straws are the greatest resource available. It is thus interesting to study barley straw in order to develop new bio-composites promoting this kind of resource. Maize and hemp do not provide the greatest quantities of by-products of their respective families. However, they both have huge potential: maize is the cereal most produced in the world [36] and France is the biggest hemp producer in Europe [27]. Forthcoming studies should focus on bioresources with widespread availability, such as wood residues, which represent $80 \%$ of the by-products available; flax, which yields around five times as much by-product as hemp; or beetroot residue, which constitutes the largest by-product by weight from agro-industry.

\subsubsection{Microscopic description}

The morphology and porous structure of the plant particles are illustrated by the SEM images

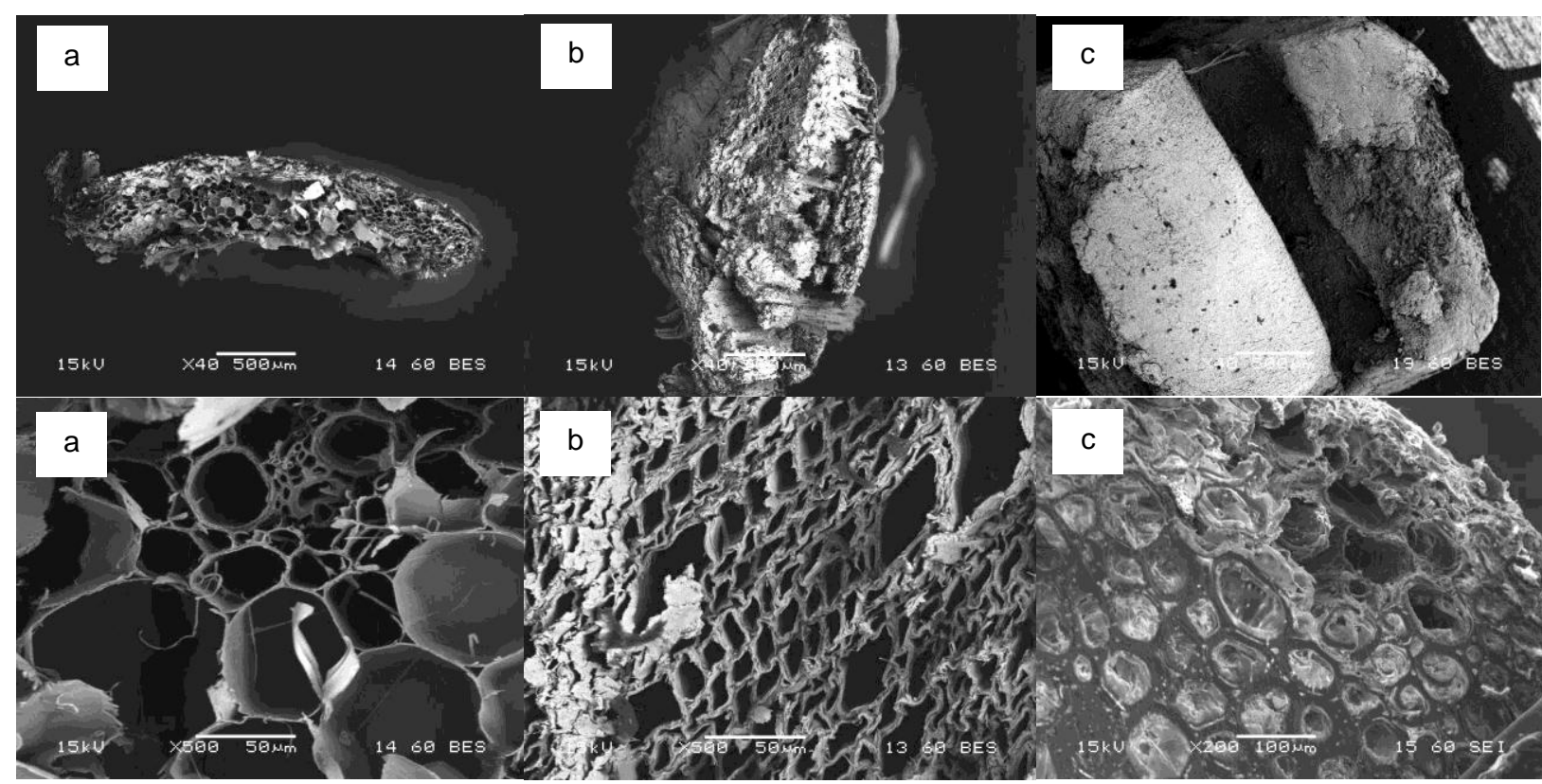
of Fig.7.

\section{1 (second line) magnification factors}

These SEM images clearly show a tubular microstructure for the three materials. However, some differences can be observed. The pores of the straw, from 2 to $100 \mu \mathrm{m}$, are multi-scale and the cell walls are very thin (maximum thickness of $2 \mu \mathrm{m}$ ). Hemp shiv pores range from 5 to $40 \mu \mathrm{m}$ and the particles present regular cell walls $4 \mu \mathrm{m}$ thick on average. Concerning corn

$357 \mathrm{cob}$, the diameter of the pores is between 20 and $80 \mu \mathrm{m}$ with a thick cell wall of up to $45 \mu \mathrm{m}$.

358 The fact that the parenchyma is thicker for corn cob than for hemp shiv or straw indicates a 
lower macro-porosity and thus a higher density of the plant particle. According to Pinto et al.

360 [51], this could lead to a strength capacity comparable to that of soft woods.

361

362

363

364

365

366

367

368

369

370

371

372

373

374

375

\subsubsection{Particle size analysis}

The particle size distribution of plant aggregates seems to have an influence on the mechanical performance of bio-based building materials. For example, Millogo et al. have shown that the compressive strength of an earth-based composite with short pieces of straw $(3 \mathrm{~cm})$ is higher than that of similar composite with longer pieces $(6 \mathrm{~cm})$ [4]. Conversely, in the case of hemp concrete, it has been shown that the coarser the hemp shiv is, the higher is the mechanical performance at 28 days [11], [52]. Danso et al. [53] have studied the effect of fibre aspect ratio on mechanical strength in an earth matrix. Compressive and tensile strengths improved for coconut, oil palm and bagasse fibres when the major axes increased. In this study, the morphological characteristics of straw, hemp shiv and corn cob were compared. Dust content, determined by sieving at $500 \mu \mathrm{m}$, was about $7.2 \%, 2.1 \%$ and $0.3 \%$ respectively for the straw, hemp shiv and corn cob. The grading curves are presented in Fig.8. Averages and standard deviations of the major and minor axes, EAD or aspect ratio were calculated from equations 8 and 9 [40] and are presented in Table 1.

$$
\begin{gathered}
E_{a m}(x)=\frac{\sum A_{i}\left(x_{i}\right)}{\sum A_{i}} \\
S d_{a m}(x)=\sqrt{\frac{\sum A_{i}\left(x_{i}-E_{a m}(x)\right)^{2}}{\sum A_{i}}}
\end{gathered}
$$

376 where $E_{a m}(x)$ is the arithmetic mean of the dimension $x$ (Major, Minor, $E A D$ or $A R$ ), $A_{i}$ is the 377 projected area of each particle detected $\left(\mathrm{mm}^{2}\right), x_{i}$ is the dimension of each particle detected and $\mathrm{Sd}_{\mathrm{am}}(\mathrm{x})$ is the associated standard deviation.

\begin{tabular}{cccc}
\hline Dimension & Barley straw & Hemp shiv & Corn cob \\
\hline Major $(\mathrm{mm})$ & $7.6 \pm 4.4$ & $5.6 \pm 2.6$ & $3.6 \pm 0.8$ \\
Minor $(\mathrm{mm})$ & $2.3 \pm 1.5$ & $2.0 \pm 1.2$ & $2.6 \pm 0.4$ \\
EAD $(\mathrm{mm})$ & $4.0 \pm 2.1$ & $3.3 \pm 1.6$ & $3.1 \pm 0.5$ \\
AR & $4.1 \pm 3.7$ & $3.3 \pm 2.0$ & $1.4 \pm 0.4$
\end{tabular}

Table 1. Arithmetic means and dispersions of plant aggregate dimensions

380 The standard deviations associated with the mean dimensions of barley straw and hemp shiv are higher than for the corn cob. This is due to the marked heterogeneity of these particles, which are obtained by mechanical grinding without any specific calibration process. In contrast, the standard deviation associated with the mean values of the corn cob morphological parameters is quite low since this aggregate is made up of a single granular fraction obtained after an industrial process of calibration. 


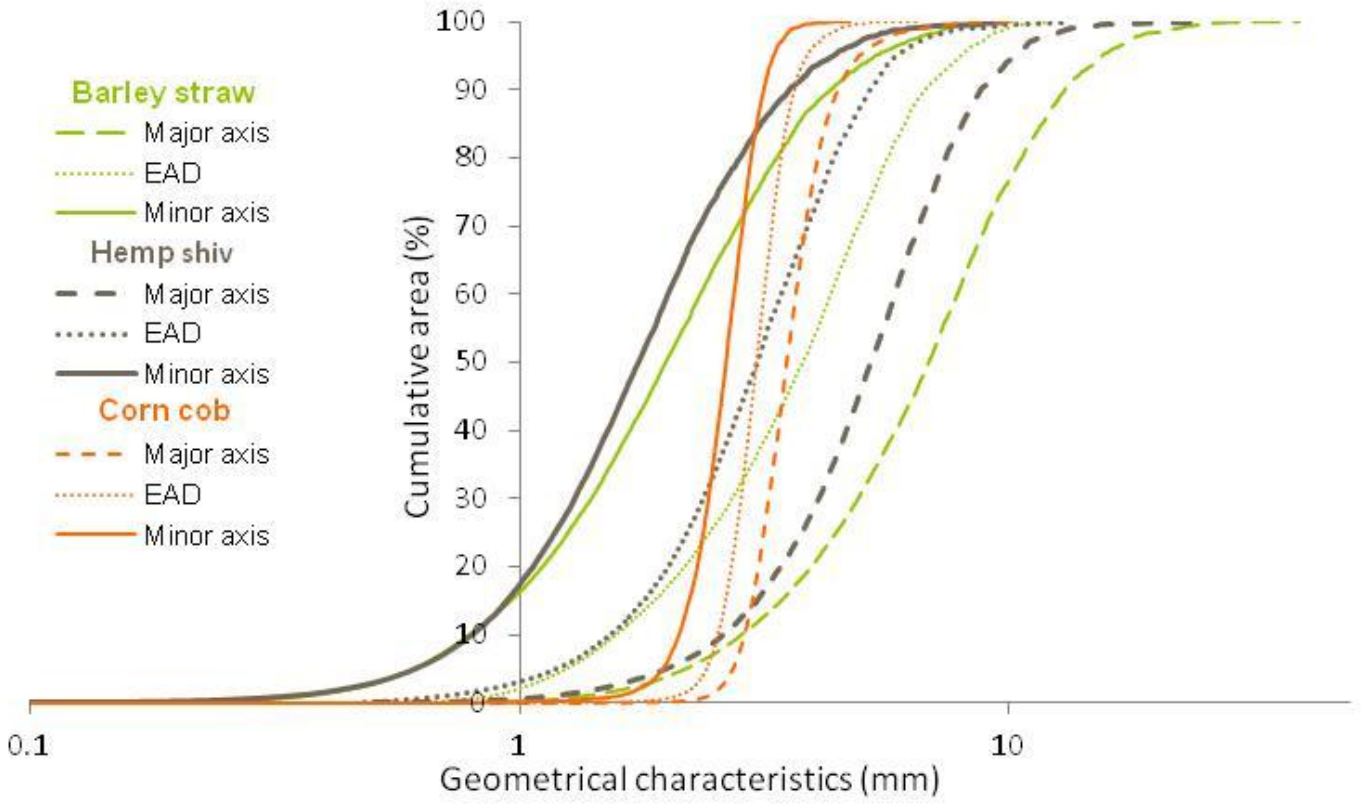

Fig. 8 Grading curves of the plant aggregates as a function of the cumulative area

388 It can be observed in Fig.8 that the corn cob spindle (between the major and minor axes) is 389 the smallest and the steepest. This means that the major and minor axes are of similar 390 length and the size of the particles is fairly regular. This result is understandable because 391 corn cob is a calibrated material (by the Eurocob company). Grading curves are quite similar 392 between straw and hemp shiv. The size of straw particles is just slightly larger than the size 393 of hemp shiv particles.

394 Proportions of AR in cumulative area are represented in Fig.9.

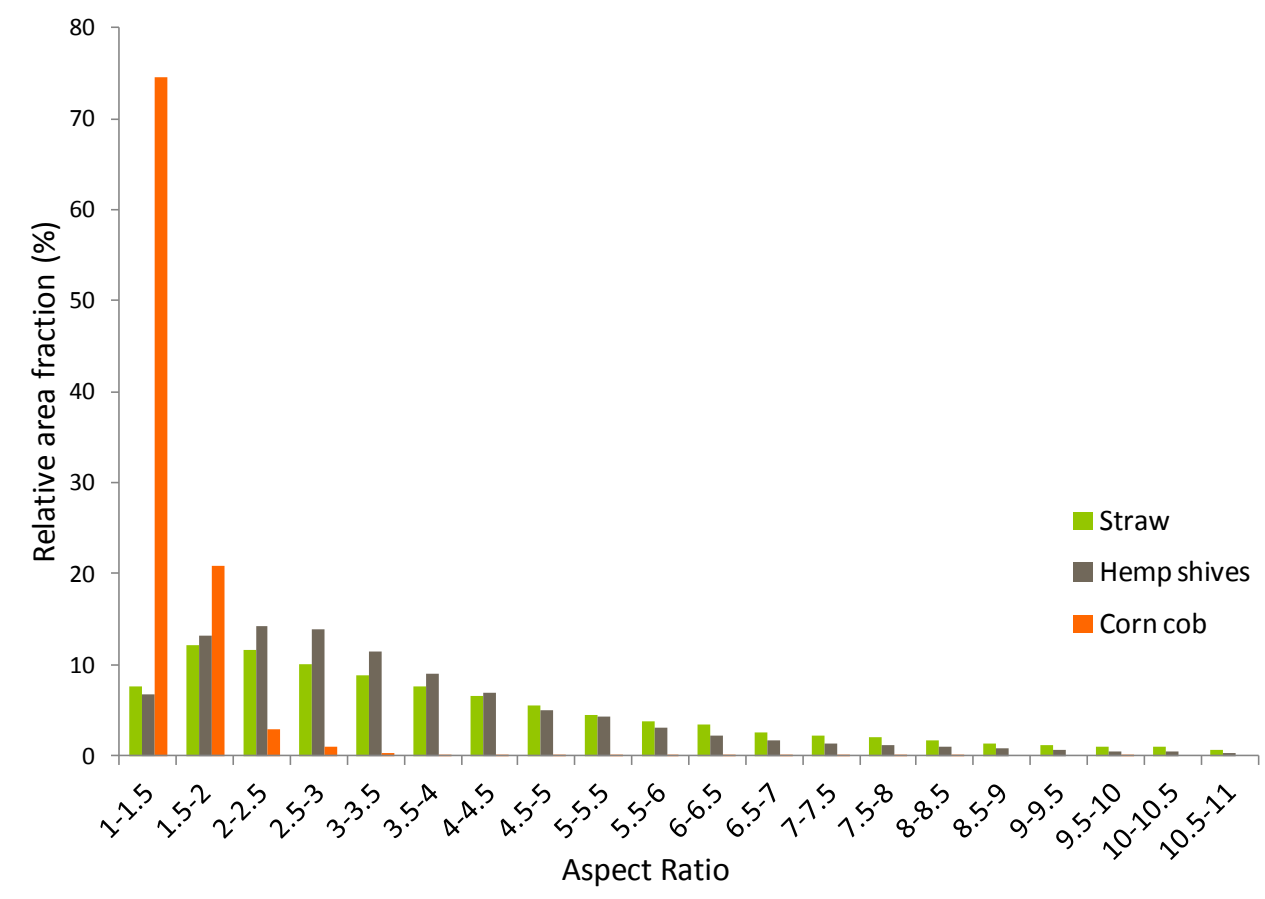

Fig.9 Relative area distribution as a function of aspect ratio 
397 It can be noted that the AR of corn cob is very close to 1, meaning that corn cob particles 398 present a nearly circular cross section. Straw and hemp shiv are more elongated (especially 399 straw) with more variation among particles.

400

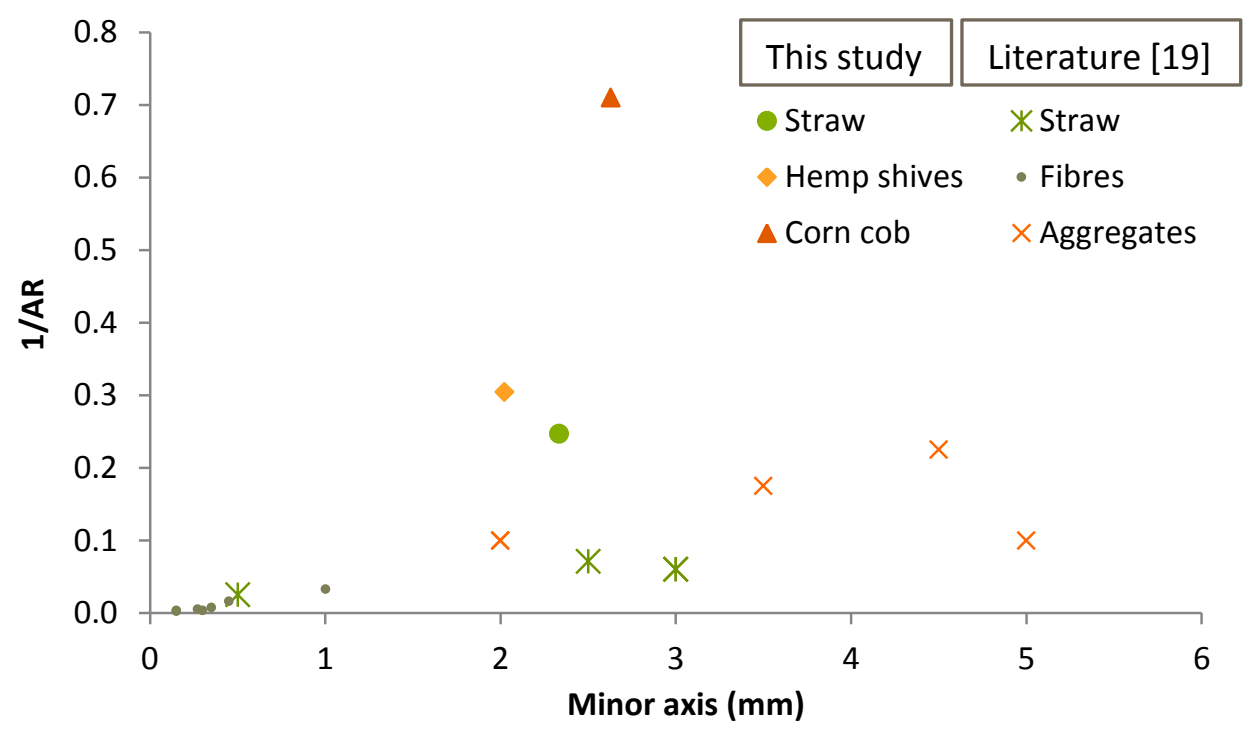

401

402 Fig.10 Reciprocal of the aspect ratio as a function of average minor axis

403 In Fig.10, the reciprocal of the AR is represented as a function of the average minor axis, in 404 order to be compared with some values found in the literature. The minor axis of this study 405 was considered to be equivalent to the diameter of the literature. These values from the 406 literature, quoted in a review by Laborel-Préneron et al. [19], were classified by type of 407 particle: fibres, aggregates and straw. Their AR was lower than that of the aggregates 408 studied here, although their minor axes were of the same order of magnitude as in the 409 particles of this study. For the straw, this can be explained by the shortness of our particles 410 even though the diameter was similar to those in the literature. Hemp shiv was more crushed 411 and finer than in the literature and corn cob was almost spherical, which is not very common 412 for plant aggregates.

413 Optimizing the particle size distribution could be an interesting lever to improve the 414 compactness of the particle arrangement of bio-based building materials, as is common for 415 basic concretes. The selection of specific particle fractions or the combination of particles 416 with different morphologies could lead to an enhancement of their mechanical performances.

\subsubsection{Bulk density and thermal conductivity}

419 Using insulating materials in buildings is a way to save energy. Adding some vegetal 420 particles into existing building materials such as earth or concrete is a means of reducing 421 their density and thus improving their thermal insulation [6], [54]. Such particles can also be 
applied in buildings as loose-fill insulation. Bulk density (Table 2) and thermal conductivity 423 (Table 3) are presented together, because thermal conductivity is highly dependent on the 424 density [19].

\begin{tabular}{cccc}
\hline Plant aggregate & Barley straw & Hemp shiv & Corn cob \\
\hline This study & $57 \pm 1$ & $153 \pm 2$ & $497 \pm 14$ \\
Literature & $47[55]$ & $110.9[9]$ & $450[58]$ \\
& $116[56]$ & $148.3[57]$ & $495[57]$ \\
& & $130[29]$ & \\
\hline
\end{tabular}

425

426

427

428

429

430

431

432

433 434

Table 2. Bulk densities $\left(\mathrm{kg} \cdot \mathrm{m}^{-3}\right)$ of the plant aggregates studied

Table 2 presents the average bulk density of each plant aggregate with the standard deviation and some values from the literature. The values from this study are close to the values from literature, except for one value for barley straw. This difference may be due the length of the straw or the method used to measure it. Barley straw has the lowest bulk density, followed by hemp shiv and then corn cob, which has the highest. The coefficients of variation are 2.0, 1.6 and $2.8 \%$ respectively for straw, hemp shiv and corn cob. This value is lower than $5 \%$ which suggests good representativeness of the different samples.

\begin{tabular}{cccc}
\hline Plant aggregate & Barley straw & Hemp shiv & Corn cob \\
\hline This study & $0.044 \pm 0.001$ & $0.051 \pm 0.002$ & $0.096 \pm 0.001$ \\
Literature & $0.035-0.054[22]$ & $0.058[9]$ & $0.099[57]$ \\
& & $0.055[28]$ & \\
& & $0.057[42]$ & \\
\hline
\end{tabular}

Table 3. Thermal conductivity $\left(\mathrm{W} \cdot \mathrm{m}^{-1} \cdot \mathrm{K}^{-1}\right)$ of the plant aggregates studied

436 Table 3 shows that the thermal conductivity values measured were similar to those found in 437 the literature. The coefficients of variation are 1.4, 3.9 and 1.1\% respectively for straw, hemp 438 shiv and corn cob. This value is lower than $5 \%$ which suggests good representativeness of 439 the different samples. Moreover, the water uptake during the test was lower than $0.2 \%$ for 440 each specimen. The moisture content, influencing thermal conductivity, can thus be 441 neglected.

442 Fig.11 compares the thermal conductivity of various plant aggregates from this study and the 443 literature in function of their bulk densities. The relation plotted is linear: the lower the bulk 444 density is, the lower is the thermal conductivity. Thermal conductivity depends mostly on the 445 bulk density. However, there are small variations even within a given particle type. They can 446 be explained by the difference in moisture content or in the testing method. The type of 447 vegetal does not seem to influence the thermal conductivity significantly, but more results 448 would be needed to confirm that hypothesis. 
449 The barley straw and hemp shiv characterized in this study present bulk densities and 450 thermal conductivities similar to those of loose-fill insulation materials such as cellulose 451 wadding or glass fibre (quoted in Goodhew and Griffiths [59]). Maskell et al. [60] 452 characterized other natural loose-fill insulation materials: wool, hemp fibre and wood fibre.

453 Such lightweight aggregates could be used in great quantities in an earth matrix as was done 454 by Labat et al. [5] with an earth clay material. The density was $241 \mathrm{~kg} \cdot \mathrm{m}^{-3}$ for a thermal 455 conductivity of $0.071 \mathrm{~W} \cdot \mathrm{m}^{-1} \cdot \mathrm{K}^{-1}$, much lower than for a traditional earth material, for which the 456 corresponding values are between 1940 and $2007 \mathrm{~kg} \cdot \mathrm{m}^{-3}$ and 0.47 and $0.59 \mathrm{~W} \cdot \mathrm{m}^{-1} \cdot \mathrm{K}^{-1}$ [49]. 457 As far as hemp concrete is concerned, it presents a thermal conductivity between 0.06 and $458 \quad 0.19 \mathrm{~W} \cdot \mathrm{m}^{-1} \cdot \mathrm{K}^{-1}$ for a dry density between 200 and $840 \mathrm{~kg} \cdot \mathrm{m}^{-3}$ [29].

459

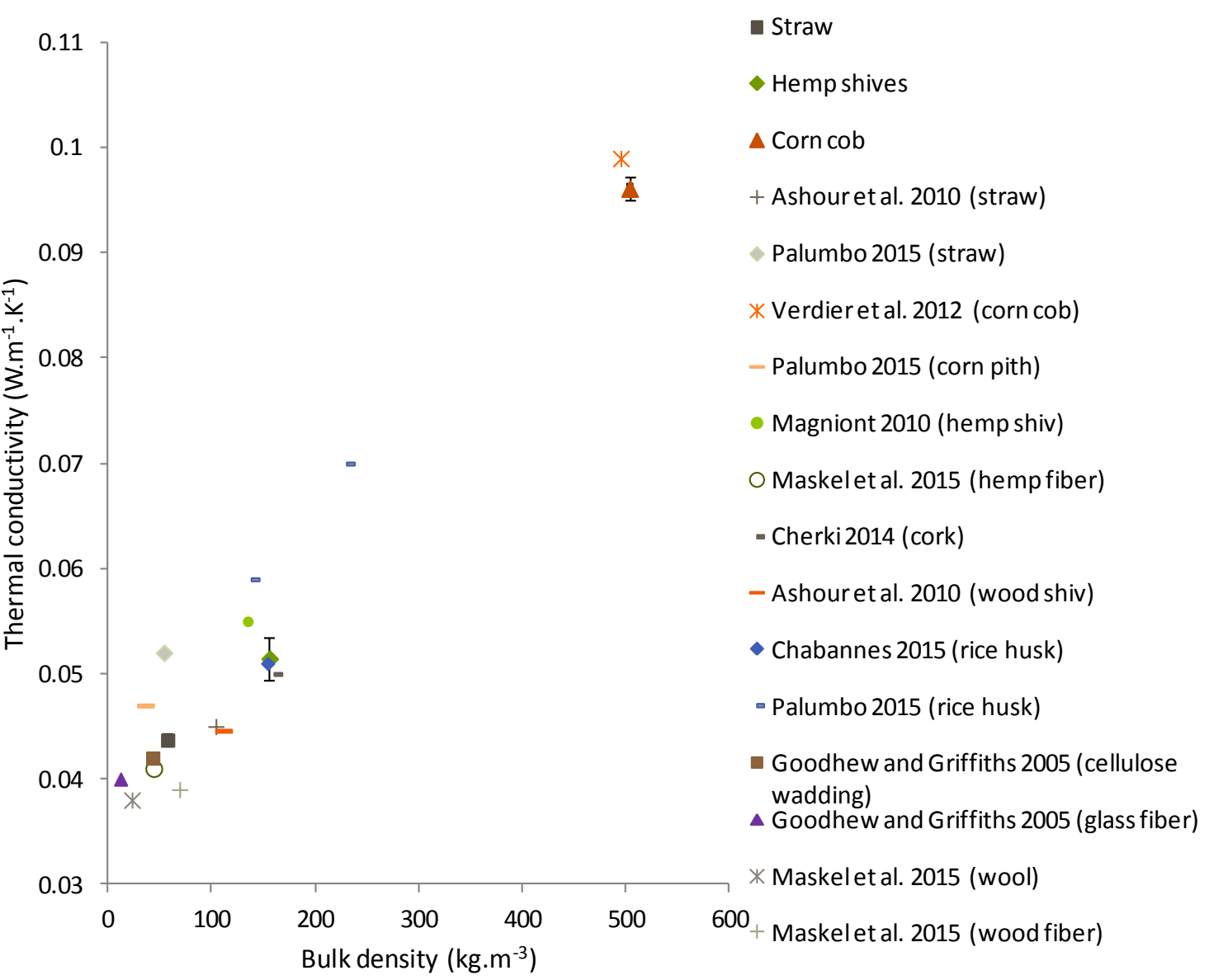

Fig.11 Comparison of thermal conductivity values measured experimentally for straw, hemp shiv and corn cob and values found in the literature

464 These materials, especially barley straw and hemp shiv, could thus be used either as lightweight aggregates to improve the thermal insulation properties of an earth or mineral matrix, or as loose-fill insulation materials. A material is considered to be a thermal insulator when the thermal conductivity is lower than $0.065 \mathrm{~W} \cdot \mathrm{m}^{-1} \cdot \mathrm{K}^{-1}$ [61]. However, the thermal conductivity found for these agro-resources was measured for particles in the dry state and it 
is known that thermal conductivity increases with relative humidity [62]. The round robin tests of RILEM TC 236 BBM [35] revealed an increase of the thermal conductivity by $12.9 \%$

471 between the dry state and a relative humidity of $50 \%$. If that increase is applied to the values 472 measured for the dried plant aggregates, thermal conductivities become $0.049 \mathrm{~W} \cdot \mathrm{m}^{-1} \cdot \mathrm{K}^{-1}$ for 473 straw, $0.058 \mathrm{~W} . \mathrm{m}^{-1} \cdot \mathrm{K}^{-1}$ for hemp shiv and $0.109 \mathrm{~W} \cdot \mathrm{m}^{-1} \cdot \mathrm{K}^{-1}$ for corn cob. In the case of straw and hemp shiv, these estimated values are still lower than the value expected for an insulation material.

\subsubsection{Water absorption}

Within a hydraulic matrix, plant aggregate water absorption is an important formulation parameter as competition can occur between the particle absorption and the matrix hydration

480 [9], leading to potential problems. Consequently, the amount of mixing water has to be largely overestimated. This implies a very long drying time, hardly compatible with the current rate of building. Water absorption was evaluated for up to $48 \mathrm{~h}$ for the three kinds of aggregates (Table 4).

484

\begin{tabular}{cccc}
\hline Plant aggregate & Barley straw & Hemp shiv & Corn cob \\
\hline This study & $414 \pm 4$ & $380 \pm 11$ & $123 \pm 2$ \\
Literature & $500-600[25]$ & $280[30]$ & $90[58]$ \\
& $400[55]$ & $301[9]$ & $\sim 150[57]$ \\
\hline
\end{tabular}

Table 4. Absorption capacity (\%) after $48 \mathrm{~h}$ of immersion

486

487

488

489

490

491

492

493

494

495

496

497

498

Maximum absorption was $414 \%$ for straw followed by $380 \%$ for hemp shiv and $123 \%$ for corn cob in the present work. Calculating the coefficients of variation gave $1.1 \%$ for barley straw, $2.8 \%$ for hemp shiv and $1.3 \%$ for corn cob. These values are lower than $5 \%$, which indicates good representativeness. These retention capacities seemed to be consistent with the literature, which presents nevertheless a high range of water absorption. This high variability could be due to the diversity of the plant particle itself or to the test method used. Only the value from [9] was obtained with the same protocol. Absorbent paper was used in references [30], [57] and the method used was not specified in the other cases. The low water absorption of corn cob could be interesting because, according to Bouhicha et al. [25], a high retention capacity is not good for adhesion to a soil matrix. During the manufacturing process, the swelling of the particles engendered by water absorption in the first 24 hours pushes the soil away. Then, when the composite material dries, shrinkage creates voids around the particles at the interface with the soil [63]. 


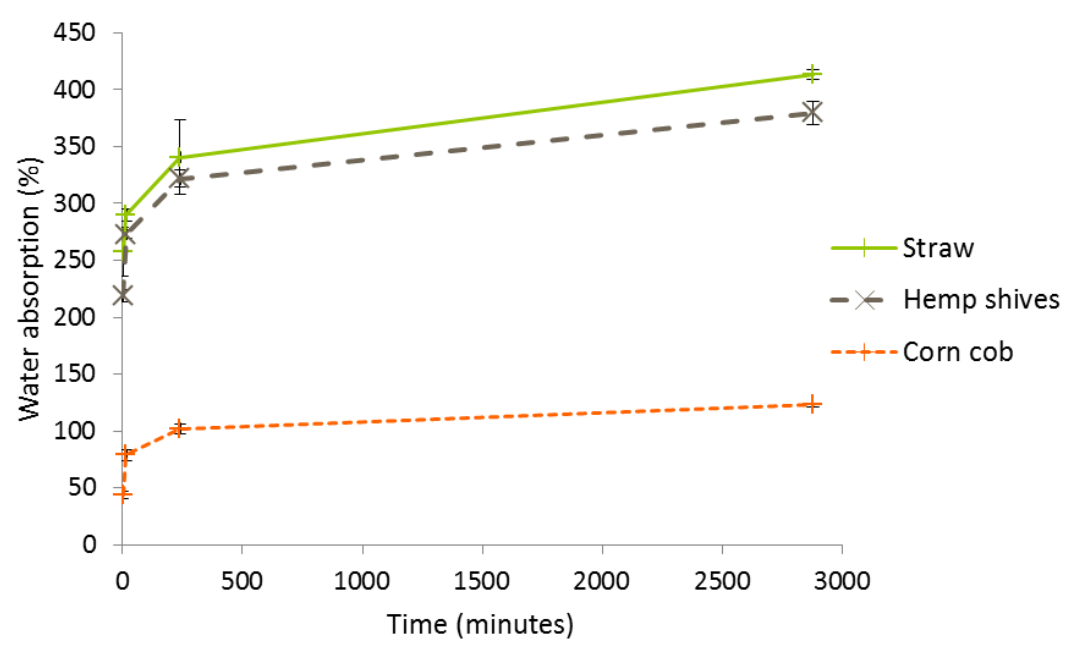

500 Fig.12 Water absorption as a function of time

501 The kinetics of this absorption is presented in Fig.12. It is very fast for these plant 502 aggregates: absorption by straw and hemp shiv at 1 minute is close to $60 \%$ of the final 503 absorption ( $48 \mathrm{~h}$ ) and $36 \%$ for corn cob. These curves can thus be considered in two parts: 504 the first one, with fast kinetics, represents an absorption by capillarity forces in the pores 505 filled by free water [12], [55]. The second one corresponds to a diffusion mechanism based 506 on Fick's law in the micro-pores and water bonding through openings $(20-40 \mathrm{~nm})$ in the plant 507 cell walls [64].

508 Water absorption occurs through the multi-scale porosity of the particles, especially for stems 509 such as straw and hemp shiv, which transport the sap in the plant. This water content seems 510 to be linked with the internal porosity of the material [41]. On the SEM pictures (Fig.7), high 511 internal porosity can be seen for straw and hemp shiv. Corn cob is less porous and the water 512 absorption is calculated from the particle mass, so the volume of water absorbed might not 513 be very different from that found for straw and hemp shiv. 


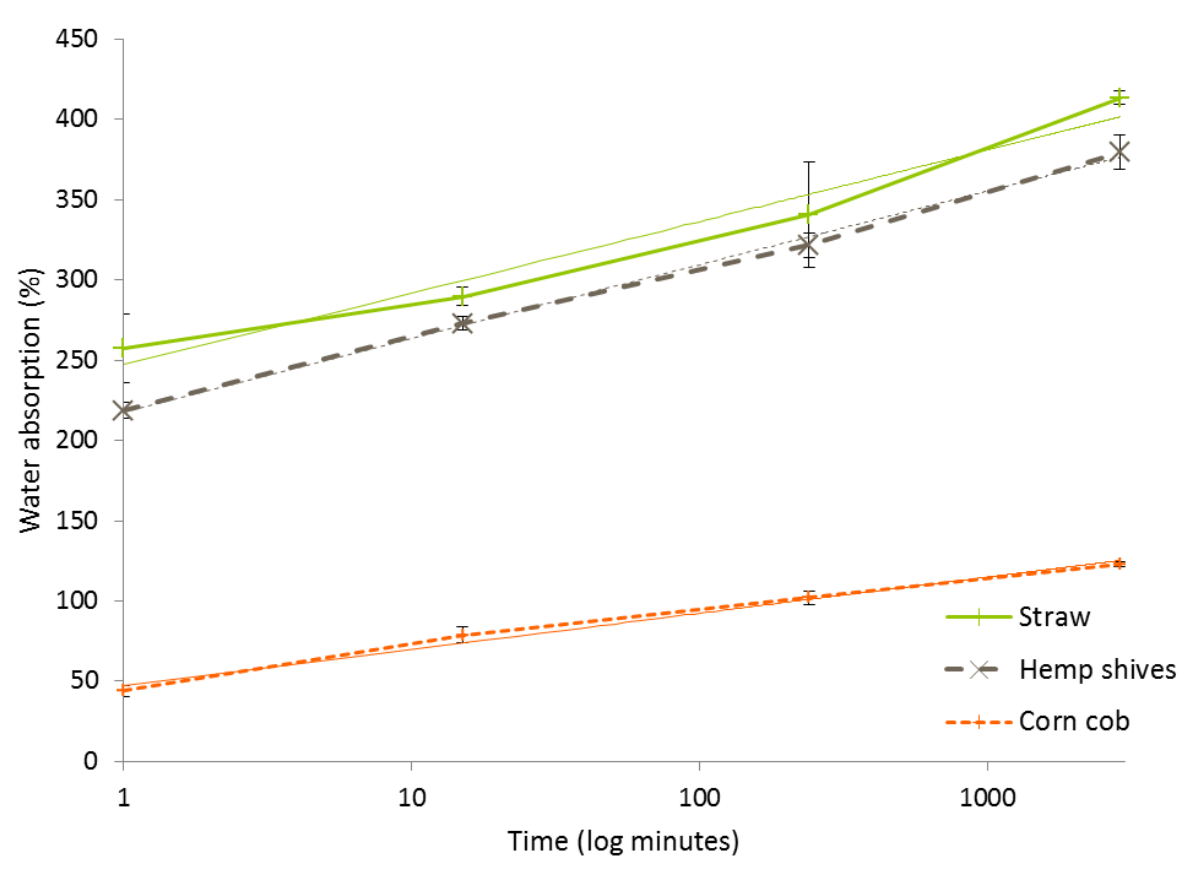

515 Fig.13 Water absorption as a function of logarithm of time

516 This absorption can be represented as a function of logarithm of time (Fig.13), where the

517 curves of the equation:

$$
W=I R A+K_{1} \times \log (t)
$$

518 proposed by Nozahic and Amziane [12], are linear. The Initial Rate of Absorption (IRA, \%) is 519 the absorption relative to an immersion of 1 minute, representing the adsorption of external 520 water on the surface of the particles [65]. $\mathrm{K}_{1}$ represents the diffusion rate in the cells (\%.(log $521 \mathrm{~min})^{-1}$ ), the second part of the curve. Both values, IRA and $\mathrm{K}_{1}$, are recapitulated in Table 5, 522 with $\mathrm{R}^{2}$, the correlation coefficient between the experimental values and the straight line.

523

\begin{tabular}{cccc}
\hline Plant aggregate & Barley straw & Hemp shiv & Corn cob \\
\hline IRA $^{\mathbf{a}}$ & 247 & 218 & 48 \\
$\mathbf{K}_{\mathbf{1}}{ }^{\mathbf{b}}$ & 19.4 & 19.9 & 9.8 \\
$\mathbf{R}^{\mathbf{2}}$ & 0.9632 & 0.9972 & 0.9874 \\
\hline${ }^{\mathrm{a}}$ IRA is the Initial Rate of Absorption; ${ }^{b} \mathrm{~K}_{1}$ represents the diffusion rate in the cells; ${ }^{\mathrm{c}} \mathrm{R}^{2}$
\end{tabular}
is the correlation coefficient

526 Table 5. Water absorption parameters

$527 \quad K_{1}$ and IRA, to a lesser extent, of barley straw and hemp shiv are very close to each other. 528 However, the logarithmic representation of barley straw water absorption is less linear $\left(R^{2}\right.$ of 529 0.96). The coefficient $K_{1}$ of corn cob is lower than the other two, meaning that the water 530 diffusion rate in the cells is quite low. 
531 As previously commented, due to the high water absorption of barley straw and hemp shiv,

532 the amount of mixing water required should be increased if these particles are added to a 533 hydraulic binder [66]. This can lead to a problematic increase of the drying time after 534 demoulding [9]. However, different treatments could be applied to reduce the water 535 absorption and drying time. Some treatments can also increase the bonding between the plant particles and the matrix. Nozahic and Amziane [12] studied three different treatments to improve the adhesion of sunflower aggregates to a mineral matrix: pre-wetting by an alkaline solution, a linseed oil coating, and a paraffin wax coating, which showed the best efficiency.

539 Other plant aggregate treatments were studied in the case of an earth matrix, such as acetylation, rosin-alcohol coating or thermal immersion in boiling water, and are summarized in Laborel-Préneron et al. [19].

\subsection{Chemical characterization}

544 The chemical characterization of plant aggregates is important in the case of bio-composites 545 with hydraulic binder as chemical composition can influence their properties or those of the composites, such as setting time or hydration mechanisms.

547 Lignocellulosic raw materials are composed of three main components: cellulose, 548 hemicellulose and lignin. There are also other chemical species present such as pectin, 549 extractives and ash. Cellulose, a polymer containing various alcoholic hydroxyl groups, can 550 significantly affect the mechanical performance of the fibres [67]. Hemicellulose is a highly 551 hydrophilic component, easily hydrolysed by acids and soluble in dilute alkali solutions. This could thus influence the water absorption of the plant particle and affect its durability in an alkaline mineral matrix, such as cement or lime, and the bonding mechanisms at the interface in these composite materials [68]. Lignin is a polymer able to protect the stem of the plant from chemical or physical aggressions, notably from most microbial attacks. The nature and the amount of lignin thus affect the durability and the biodegradability of the distinct vegetal materials [67]. A variety of functions is attributed to pectins, including mechanical properties, cell-cell adhesion, wall porosity and binding of ions [69]. An affinity between pectin and cations exists and could affect the setting mechanisms of mineral binders

560 (Portland cement, lime, etc.) used in bioaggregate-based composites.

These interactions can take place at different times. At early age, they can disturb the setting and hardening mechanisms of mineral binders. Hemp shiv [70], hemp fibres [71], wood particles [72-75], cereal straw [76], [77] (cited in [78]), arhar stalks [79], sugar cane bagasse [80] and coir particles [81], among others, have been shown to negatively impact the setting and early hardening of cement paste. Wood particles can also be associated with a plaster matrix (calcium sulfate hemihydrate). Boustingorry et al. [82] emphasized that poplar and 
568 forest pine extracts clearly delayed the hydration of hemihydrate. Finally, the setting of a 569 pozzolanic binder (mix of lime and metakaolin) has been shown to be affected by the 570 presence of lavender stalks [13]. In the hardened state, they can modify the properties of the 571 composite. Poor cohesion has been observed between plant aggregates and the mineral 572 matrix, associated with a powdering of the binder [70]. In the long term, they can influence 573 the durability of the material through mineralization of the plant aggregates by cement 574 hydration products [83]. This engenders a loss of ductility of the fibres, which is a 575 disadvantage for plant fibre reinforced concrete, which has to work in flexion. However, it 576 might be an advantage for bioaggregate-based composites, leading to a continuous 577 enhancement of compressive strength [84].

579 The chemical composition of the three plant aggregates is presented in Table 6 and 580 compared with some other values from the literature. Values are expressed in percentage of 581 dry mass of the plant material. The column "Extractives" refers to the water-soluble content 582 (this study), the sum of pectin, wax, fat and protein, or the content obtained with Soxhlet 583 extraction (literature).

584

\begin{tabular}{ccccccc}
\hline Aggregate & Reference & Lignin (\%) & Cellulose (\%) & $\begin{array}{c}\text { Hemicellulose } \\
\text { (\%) }\end{array}$ & Extractives (\%) & Ash (\%) \\
\hline \multirow{3}{*}{ Barley straw } & This study & 5.5 & 37.7 & 26.7 & 14.4 & 12.3 \\
\cline { 2 - 8 } & {$[85]$} & 15.8 & 37.6 & 34.9 & - & - \\
\cline { 2 - 8 } & {$[86]$} & 15 & 46 & 23 & - & - \\
\hline \multirow{5}{*}{ Hemp shiv } & This study & 17.2 & 50.3 & 17.9 & 5.9 & 2.1 \\
\cline { 2 - 8 } & {$[87]$} & 18 & 52 & 9 & - & 2 \\
\cline { 2 - 7 } & {$[88]$} & 22.1 & 37.7 & 26.8 & 8.9 & - \\
\cline { 2 - 7 } & {$[70]$} & $21.8-23.3$ & $45.6-49.2$ & $17.8-21$ & $5.1-6.2$ & $2.6-3.7$ \\
\cline { 2 - 7 } & {$[89],[90]$} & 28 & 48 & 12 & 10 & 2 \\
\cline { 2 - 7 } & {$[91]$} & 28 & 44 & 18 & 10 & 2 \\
\hline \multirow{3}{*}{ Corn cob } & This study & 6.6 & 41.4 & 40.7 & 6.9 & 1.2 \\
\cline { 2 - 7 } & {$[58]$} & 6.8 & 47.1 & 37.3 & - & 1.2 \\
\cline { 2 - 7 } & {$[93]$} & $6.7-13.9$ & $32.5-45.6$ & 39.8 & - & - \\
\cline { 2 - 7 } & {$[68]$} & 14.7 & 48.1 & 37.2 & 7 & - \\
\hline
\end{tabular}

585 Table 6. Chemical composition of the 3 plant aggregates

586 Among the three types of particles studied, barley straw showed the highest amount of 587 extractives (14.4\%) and ash (12.3\%). The extractive contents of hemp shiv and corn cob 588 were 5.2 and $6.9 \%$, respectively. The ash content of these two aggregates was also lower, at 5892.1 and $1.4 \%$. It is important to take the extractives content into account because it is the 590 main cause of interactions with the hydraulic binder. 
591 These chemical compositions are represented in a ternary diagram showing lignin, cellulose 592 and hemicellulose (Fig.14). The values are normalized to $100 \%$, as in [68]. The comparison of 593 the composition of particles is facilitated by this presentation. The plant aggregates used in 594 this study are circled in red.

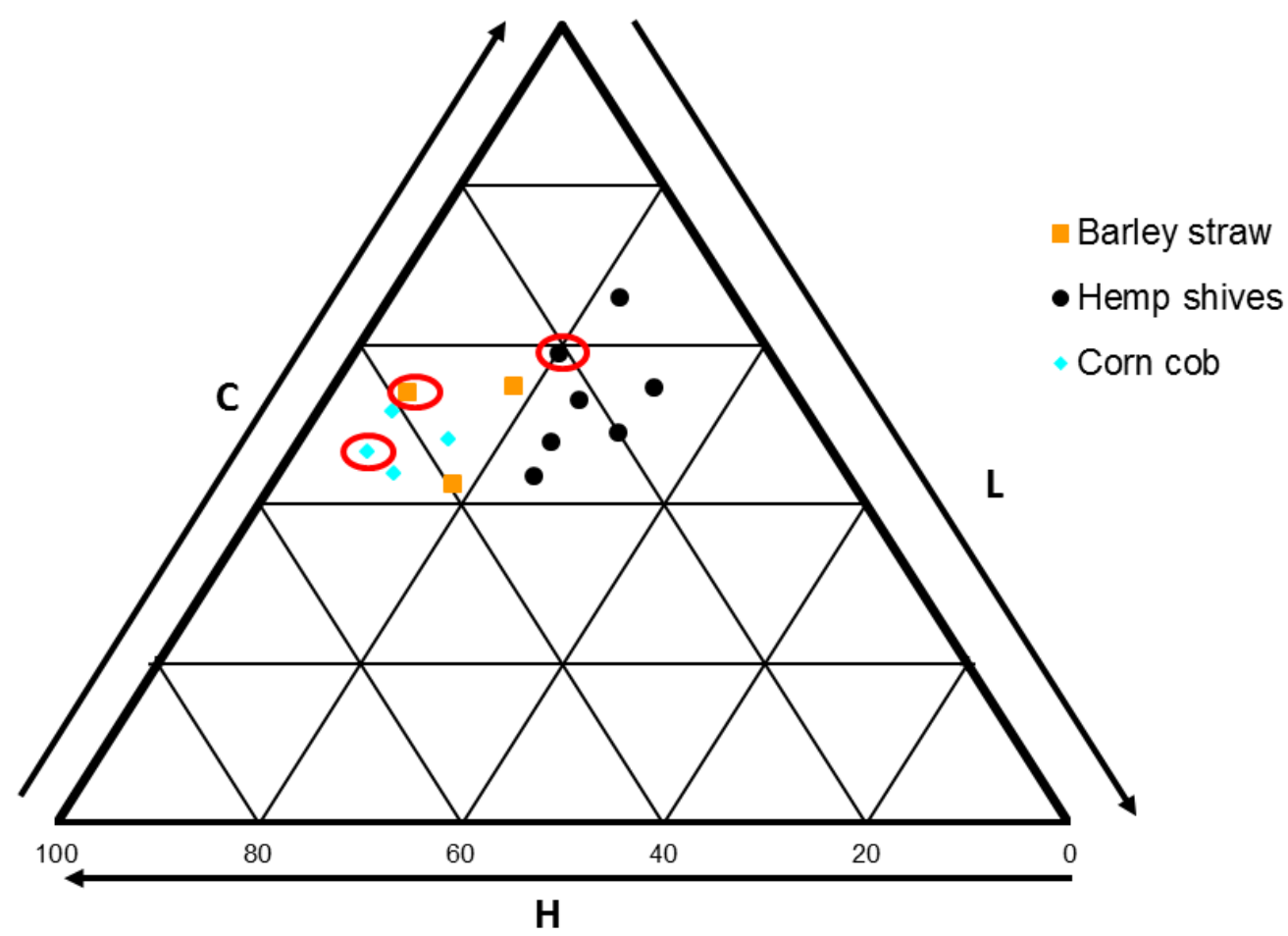

595

Fig.14 Chemical composition of the 3 plant aggregates

597 All the bioaggregates were rich in cellulose, which several authors link to the mechanical 598 performance of the aggregate [67], [94], [95]. Corn cob was the aggregate presenting the 599 highest hemicellulose content, a component easily dissolved by alkaline attack. It is thus the 600 least usable in an alkaline mineral matrix. The lignin content was higher for hemp shiv. This 601 aggregate could thus be the most durable of the three types.

602 Values for a type of aggregate are quite scattered. These variations may be due to the 603 measurement method used but may also be connected with differences in the maturity of the 604 stems, the season of harvest, the variety or, in the case of hemp, the retting process [96].

605

606

3.4. Sorption-desorption isotherms (DVS)

607 Fig.15 presents the sorption-desorption isotherms of the 3 plant aggregates. 


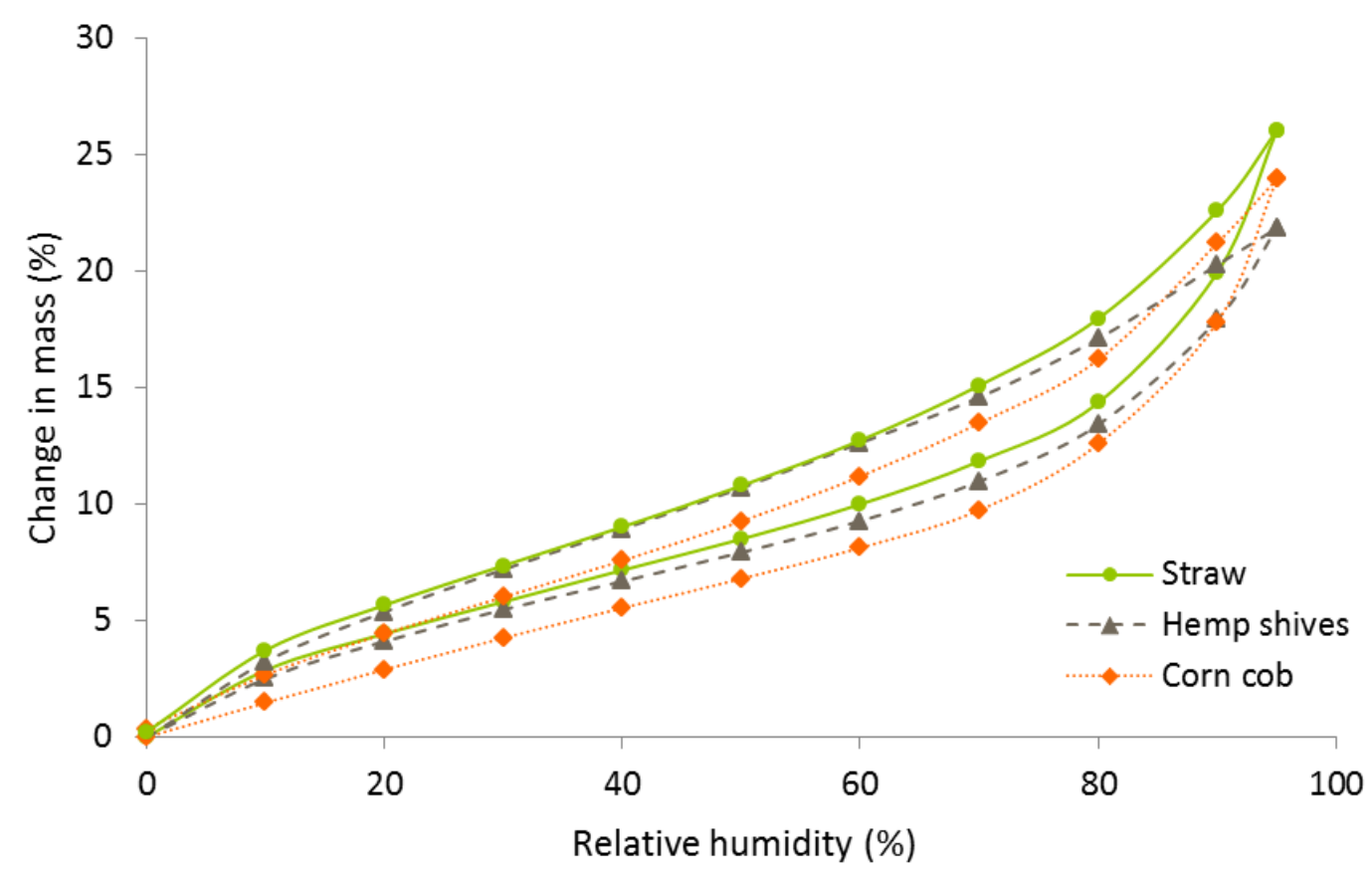

608

609 Fig.15 DVS water vapour sorption isotherm of the 3 plant aggregates at $23^{\circ} \mathrm{C}$

610 The shape of the sorption curves is similar for all the particles and corresponds to a 611 sigmoidal isotherm, Type II according to the IUPAC (International Union of Pure and Applied 612 Chemistry) classification. This result is very common for cellulosic and lignocellulosic 613 materials [34]. Although the results are similar for the three aggregate types, straw has a 614 slightly higher sorption value at high relative humidity (but below $90 \%$ of relative humidity), 615 followed by hemp shiv and corn cob.

616

617 Hysteresis (Fig.16) represents the gap between the sorption and desorption isotherms 618 (moisture content in desorption is higher than in sorption). This phenomenon is commonly 619 explained by capillary condensation, the ink-bottle effect and the contact angle difference 620 between adsorption and desorption [97], [98]. This phenomenon also seems to be influenced 621 by the lignin content of the natural fibres [98]. The hysteresis values, ranging from 0.1 to $6223.8 \%$, increase with relative humidity except for the last 1 or 2 steps. They are comparable 623 for the three plant particles. 


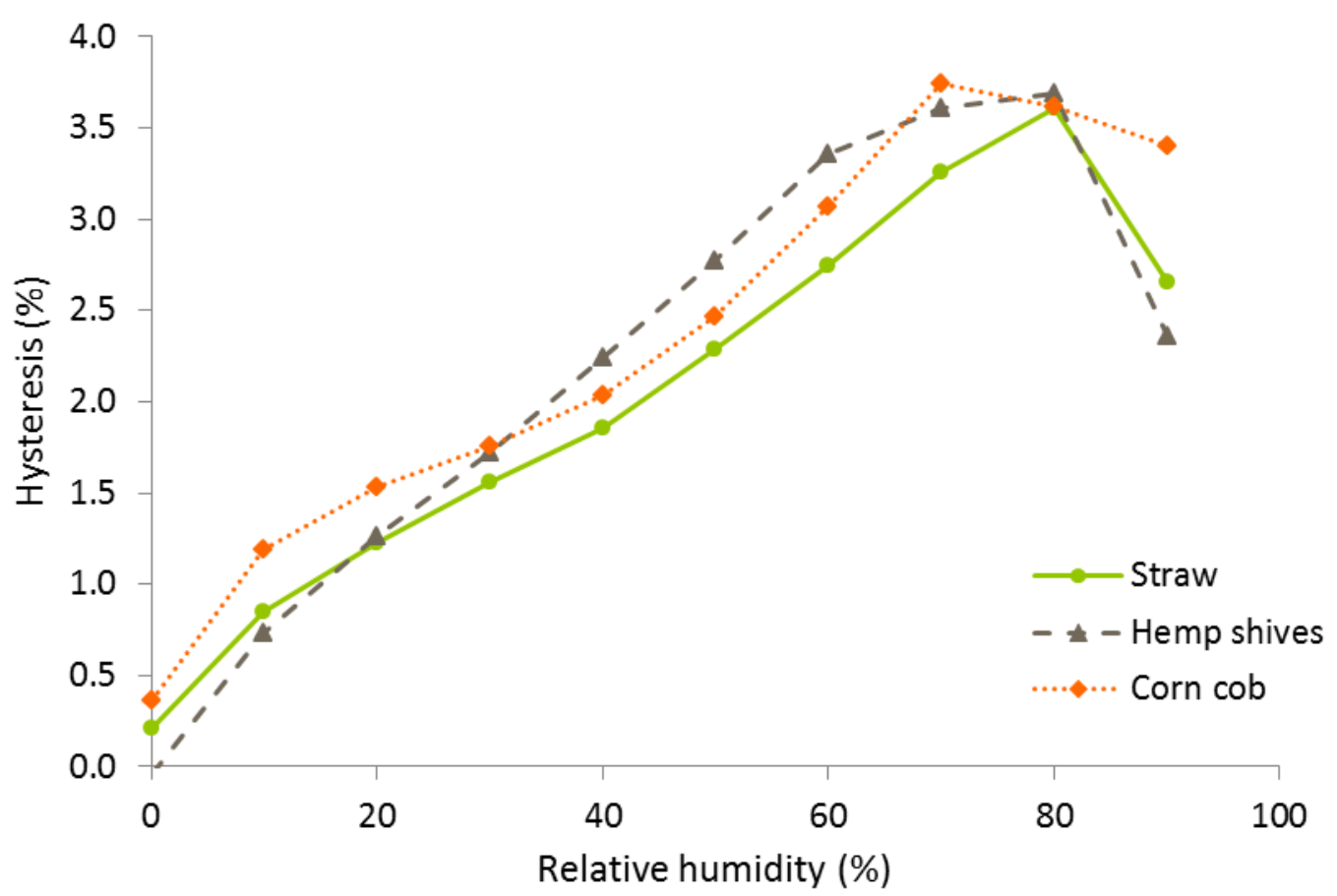

624

Fig.16 Hysteresis calculated from the sorption and desorption isotherms of the 3 plant aggregates at $23^{\circ} \mathrm{C}$

These plant aggregates, whose sorption values reach 20 to $26 \%$ at $95 \%$ of relative humidity, could be used as aggregates in a matrix to increase the sorption capacity of the material. A high sorption capacity could induce good moisture buffering if the kinetics of sorptiondesorption proved to be fast. This would improve the balance of the indoor air humidity, making it more comfortable for the occupant [99]. Complementary tests to study the kinetics of the sorption and desorption of each materials would be necessary to conclude on the subject of moisture buffering. This improvement has already been studied by Ashour et al. [100] with straw added to an earth plaster. The sorption capacity improved from $1.7 \%$ for earth alone to $6.5 \%$ with the addition of $75 \%$ of straw by volume.

At $80 \% \mathrm{RH}$, the sorption capacity of a lime plaster studied by Černý et al. 2006 [101] was lower than $1 \%$ and those of pozzolanic lime plasters were up to $4 \%$. The sorption capacity of the plant aggregates of this study was between 12 and 14\%. Their addition to that kind of mineral matrix could increase the sorption capacity of the composite material.

\section{CONCLUSION}

In this paper, three potential resources for bio-based building materials were characterized: barley straw, hemp shiv and corn cob. Their availability in France, physical properties, chemical composition and hygric properties were investigated. This overall methodology is mostly adapted from the RILEM method for characterizing bio-based aggregates. Although the round robin test was performed for hemp shiv, it can be adapted to other plant particles: 
647 the mass of the samples should be modified according to the bulk density of the particle type.

648 However, image analysis may be less useful in the case of spherical particles, such as corn

649 cob, which can be characterized by the faster sieving method, as is done for mineral 650 aggregate. The study of the availability of plants was deliberately restricted to France, as the 651 use of local resources allows the environmental impact to be limited. Nevertheless, this kind 652 of investigation should be carried out to evaluate the potential each time an agro-resource is 653 considered for the development of a new bio-based material.

654 The main results are summarized below:

655 - Barley straw is a resource having good availability, with more than 4 million tons available 656 each year. Corn cob and hemp shiv also present an interesting potential with 240000 and 17000 tons of by-products available each year.

- The microstructure of these three aggregates is composed of tubular pores, but with a different cell wall thickness for each type.

- Bulk density, highly dependent on these microstructures, is around 60,150 and 500 kg.m ${ }^{3}$ respectively for the straw, hemp shiv and corn cob.

- Thermal conductivity is, like bulk density, the lowest for straw, followed by hemp shiv and then corn cob.

- The morphology of the particles is quite similar for straw and hemp shiv (the straw being slightly more elongated) whereas corn cob aggregate is more spherical. That property could lead to different qualities of adhesion in case of use in a matrix.

- Water absorption is very high for straw and hemp shiv $(414 \%$ and $380 \%$ respectively after $48 \mathrm{~h}$ of immersion) but it is much lower for corn cob, with only $123 \%$ of water absorption.

- The chemical composition of the bioaggregates is rich in cellulose. Corn cob is rich in hemicellulose, hemp shiv has the highest lignin content (17\%) and straw presents the highest extractive and ash content (around 25\%).

674 Some conclusions can thus be drawn for each particle type. Barley straw is the most 675 available agro-resource of this study and the best thermal insulator thanks to its low bulk density. A major drawback is its high water absorption which would be prejudicial in case of 677 introduction of this straw into a pozzolanic or hydraulic matrix. It would induce the need for a 678 surplus of water leading to a longer drying time. However, there are some possibilities for 679 treating the particles to reduce this absorption and avoid its negative effects on adhesion or 680 setting time. Straw also presents the highest aspect ratio, which seems to be a positive factor 681 in terms of mechanical strength in an earth matrix [53]. Hemp shiv appears to be the most 682 suitable plant aggregate for use within a hydraulic matrix thanks to its lowest hemicellulose 
683 and extractive contents. The thermal conductivity of both straw and hemp shiv is compatible

684 with their use as loose-fill insulation. As far as corn cob is concerned, its use might be 685 interesting because of its low water absorption, which would avoid the earth to be expanded. 686 However, its high hemicellulose content, sensitive to alkaline attack, limits its use in a 687 pozzolanic or hydraulic matrix for example.

688 All three plant aggregates could be used in an earth matrix, where there is no risk of 689 interaction. The high vapour sorption capacity of these lignocellulosic materials could be 690 useful to improve the capacity of earth or mineral matrices to store moisture. Concerning 691 morphological parameters, it has been shown that mechanical strength is higher when 692 coarser particles are incorporated [52]. However, complementary studies will be necessary to 693 correlate morphological parameters or size distribution of the plant particles with the 694 performances of the composites. These bioaggregates show promise for the development of 695 bio-based building materials if they are used in an appropriate matrix. More research is 696 needed in order to study other parameters such as mechanical strength, fire resistance or microbial growth resistance. Other available resources should also be investigated to develop new building materials, with beetroot for instance.

699

\section{ACKNOWLEDGEMENTS}

701

The authors wish to thank the French National Research Agency - France (ANR) for funding project BIOTERRA - ANR - 13 - VBDU - 0005 Villes et Bâtiments Durables.

703

704

\section{REFERENCES}

705 [1] European Commission, "Buildings." 2016.

706 [2] Ministère de l'Environnement, de l'Energie et de la Mer, "Bâtiments et villes durables 707 Déchets du bâtiment." 2012.

708 [3] A. Shea, M. Lawrence, and P. Walker, "Hygrothermal performance of an experimental 709 hemp-lime building," Constr. Build. Mater., vol. 36, pp. 270-275, Nov. 2012.

[4] Y. Millogo, J.-C. Morel, J.-E. Aubert, and K. Ghavami, "Experimental analysis of Pressed Adobe Blocks reinforced with Hibiscus cannabinus fibers," Constr. Build. Mater., vol. 52, pp. 71-78, 2014.

[5] M. Labat, C. Magniont, N. Oudhof, and J.-E. Aubert, "From the experimental characterization of the hygrothermal properties of straw-clay mixtures to the numerical assessment of their buffering potential," Build. Environ., vol. 97, pp. 69-81, 2016.

[6] K. Al Rim, A. Ledhem, O. Douzane, R. M. Dheilly, and M. Queneudec, "Influence of the proportion of wood on the thermal and mechanical performances of clay-cement-wood composites," Cem. Concr. Compos., vol. 21, no. 4, pp. 269-276, 1999. 
[7] F. Aymerich, L. Fenu, and P. Meloni, "Effect of reinforcing wool fibres on fracture and energy absorption properties of an earthen material," Constr. Build. Mater., vol. 27, no. 1, pp. 66-72, Feb. 2012.

[8] P. Tronet, T. Lecompte, V. Picandet, and C. Baley, "Study of lime hemp composite precasting by compaction of fresh mix - An instrumented die to measure friction and stress state," Powder Technol., vol. 258, pp. 285-296, May 2014.

[9] T. M. Dinh, "Contribution to the development of precast hempcrete using innovative pozzolanic binder," PhD dissertation in Civil Engineering, Université Toulouse III - Paul Sabatier, Toulouse, 2014.

[10] C. Niyigena et al., "Variability of the mechanical properties of hemp concrete," Mater. Today Commun., vol. 7, pp. 122-133, 2016.

[11] L. Arnaud and E. Gourlay, "Experimental study of parameters influencing mechanical properties of hemp concretes," Constr. Build. Mater., vol. 28, no. 1, pp. 50-56, Mar. 2012.

[12] V. Nozahic and S. Amziane, "Influence of sunflower aggregates surface treatments on physical properties and adhesion with a mineral binder," Compos. Part Appl. Sci. Manuf., vol. 43, no. 11, pp. 1837-1849, Nov. 2012.

[13] V. Ratiarisoa, C. Magniont, S. Ginestet, C. Oms, and G. Escadeillas, "Assessment of distilled lavender stalks as bioaggregate for building materials: Hygrothermal properties, mechanical performance and chemical interactions with mineral pozzolanic binder" Constr. Build. Mater., vol. 124, pp. 801-815, Oct. 2016.

[14] M. de Wit and A. Faaij, "European biomass resource potential and costs," Biomass Bioenergy, vol. 34, no. 2, pp. 188-202, Feb. 2010.

[15] G. Fischer, S. Prieler, H. van Velthuizen, S. M. Lensink, M. Londo, and M. de Wit, "Biofuel production potentials in Europe: Sustainable use of cultivated land and pastures. Part I: Land productivity potentials," Biomass Bioenergy, vol. 34, no. 2, pp. 159-172, Feb. 2010.

[16] K. Ericsson and L. J. Nilsson, "Assessment of the potential biomass supply in Europe using a resource-focused approach," Biomass Bioenergy, vol. 30, no. 1, pp. 1-15, Jan. 2006.

[17] M. Palumbo, J. Avellaneda, and A. M. Lacasta, "Availability of crop by-products in Spain: New raw materials for natural thermal insulation," Resour. Conserv. Recycl., vol. 99, pp. 1-6, 2015.

[18] France Agrimer, "L'observatoire national des ressources en biomasse - Evaluation des ressources disponibles en France." France Agrimer, 2015. 
[19] A. Laborel-Préneron, J. E. Aubert, C. Magniont, C. Tribout, and A. Bertron, "Plant aggregates and fibers in earth construction materials: A review," Constr. Build. Mater., vol. 111, pp. 719-734, 2016.

[20] J.-E. Aubert, A. Marcom, P. Oliva, and P. Segui, "Chequered earth construction in south-western France," J. Cult. Herit., vol. 16, no. 3, pp. 293-298.

[21] E. Quagliarini and S. Lenci, "The influence of natural stabilizers and natural fibres on the mechanical properties of ancient Roman adobe bricks," J. Cult. Herit., vol. 11, no. 3, pp. 309-314, Jul. 2010.

[22] T. Ashour, H. Wieland, H. Georg, F.-J. Bockisch, and W. Wu, "The influence of natural reinforcement fibres on insulation values of earth plaster for straw bale buildings," Mater. Des., vol. 31, no. 10, pp. 4676-4685, Dec. 2010.

766

[23] L. Turanli and A. Saritas, "Strengthening the structural behavior of adobe walls through the use of plaster reinforcement mesh," Constr. Build. Mater., vol. 25, no. 4, pp. 1747-

768

769

770

771

772

773

774

775

776

777

778

779

780

781

782

783

784

785

786

787

788 1752, Apr. 2011.

[24] Ş. Yetgin, Ö. Çavdar, and A. Çavdar, "The effects of the fiber contents on the mechanic properties of the adobes," Constr. Build. Mater., vol. 22, no. 3, pp. 222-227, Mar. 2008.

[25] M. Bouhicha, F. Aouissi, and S. Kenai, "Performance of composite soil reinforced with barley straw," Cem. Concr. Compos., vol. 27, no. 5, pp. 617-621, May 2005.

[26] P. Faria, T. Santos, and J.-E. Aubert, "Experimental characterization of an earth ecoefficient plastering mortar," J. Mater. Civ. Eng., vol. 28, no. 1, 2016.

[27] Nomadéis, "Etude sur le secteur et les filières de production des matériaux et produits bio-sourcés utilisés dans la construction (à l'exception du bois)." 2012.

[28] C. Magniont, "Contribution à la formulation et à la caractérisation d'un écomatériau de construction à base d'agroressources," PhD dissertation in Civil Engieneering, Université Toulouse III - Paul Sabatier, Toulouse, 2010.

[29] V. Cerezo, "Propriétés mécaniques, thermiques et acoustiques d'un matériau à base de particules végétales: approche expérimentale et modélisation théorique," $\mathrm{PhD}$ dissertation in Civil Engineering, Institut National des Sciences Appliquées, Lyon, 2005.

[30] C. Flament, "Valorisation de fines de lavage de granulats : application à la construction en terre crue," PhD dissertation in Civil Engineering, Université d'Artois, Béthune, 2013.

[31] E. Hamard, J.-C. Morel, F. Salgado, A. Marcom, and N. Meunier, "A procedure to assess the suitability of plaster to protect vernacular earthen architecture," J. Cult. Herit., vol. 14, no. 2, pp. 109-115, Mar. 2013.

[32] J. Pinto et al., "Corn's cob as a potential ecological thermal insulation material," Energy Build., vol. 43, no. 8, pp. 1985-1990, Aug. 2011. 
[33] T. Verdier, C. Magniont, and G. Escadeillas, "Etude comparative de 3 types de particules végétales en vue de leur incorporation comme granulats légers dans une matrice minérale," presented at the NoMaD, Toulouse, France, 2012.

[34] M. Palumbo, "Contribution to the development of new bio-based thermal insulation 793 materials made from vegetal pith and natural binders," PhD Thesis, Universitat

794

795

796

797

798

799

800

801

802

803

804

805

806

807

808

809

810

811

812

813

814

815

816

817

818

819

820

821

822

823

824 Politècnica de Catalunya, Barcelona, 2015.

[35] S. Amziane, F. Collet, M. Lawrence, C. Magniont, and V. Picandet, "Round robin test for hemp shiv characterisation," in Bio-aggregates based building materials - State-of-theArt Report of the RILEM Technical Committee 236-BBM, Springer., vol. 23, Sofiane Amziane, Florence Collet, 2017.

[36] FAOSTAT, "Statistical pocketbook - World food and agriculture." 2015.

[37] Agreste, "Statistique agricole annuelle." 2014.

[38] D. Jölli and S. Giljum, "Unused biomass extraction in agriculture, forestry and fishery." Sustainable Europe Research Institute (SERI), 2005.

[39] FCBA, "Mémento 2015." 2015.

[40] V. Picandet, "Characterization of Plant-Based Aggregates," in Bio-aggregate-based Building Materials, S. Amziane, L. Arnaud, and N. Challamel, Eds. Hoboken, NJ 07030 USA: John Wiley \& Sons, Inc., 2013, pp. 27-74.

[41] M. Chabannes, V. Nozahic, and S. Amziane, "Design and multi-physical properties of a new insulating concrete using sunflower stem aggregates and eco-friendly binders," Mater. Struct., vol. 48, no. 6, pp. 1815-1829, Jun. 2015.

[42] V. Nozahic, S. Amziane, G. Torrent, K. Saïdi, and H. De Baynast, "Design of green concrete made of plant-derived aggregates and a pumice-lime binder," Cem. Concr. Compos., vol. 34, no. 2, pp. 231-241, Feb. 2012.

[43] M. Chabannes, J.-C. Bénézet, L. Clerc, and E. Garcia-Diaz, "Use of raw rice husk as natural aggregate in a lightweight insulating concrete: An innovative application," Constr. Build. Mater., vol. 70, pp. 428-438, 2014.

[44] AFNOR, "NF V18-122 - Aliments des animaux - Détermination séquentielle des constituants pariétaux - Méthode par traitement aux détergents neutre et acide et à l'acide sulfurique." 2013.

[45] F. McGregor, A. Heath, E. Fodde, and A. Shea, "Conditions affecting the moisture buffering measurement performed on compressed earth blocks," Build. Environ., vol. 75, pp. 11-18, May 2014.

[46] C. Feng, H. Janssen, Y. Feng, and Q. Meng, "Hygric properties of porous building materials: Analysis of measurement repeatability and reproducibility," Build. Environ., vol. 85, pp. 160-172, Feb. 2015. 
[47] R. Bui, M. Labat, and J.-E. Aubert, "Comparison of the Saturated Salt Solution and the Dynamic Vapor Sorption techniques based on the measured sorption isotherm of barley straw," Accepted in Constr. Build. Mater., 2017.

[48] AFNOR, "Performance hygrothermique des matériaux et produits pour le bâtiment Détermination des propriétés de sorption hygroscopique." NF EN ISO 12571, 2013.

[49] H. Cagnon, J. E. Aubert, M. Coutand, and C. Magniont, "Hygrothermal properties of earth bricks," Energy Build., vol. 80, pp. 208-217, Sep. 2014.

[50] Association Construire en Chanvre, "Exécution d'ouvrages en bétons de chanvre : mur en béton de chanvre, isolation de sol en béton de chanvre, isolation de toiture en béton de chanvre, enduits en mortier de chanvre (Règles professionnelles)." Société d'édition du bâtiment et des travaux publics, 2012.

[51] J. Pinto et al., "Characterization of corn cob as a possible raw building material," Constr. Build. Mater., vol. 34, pp. 28-33, Sep. 2012.

[52] T. T. Nguyen, "Contribution à l'étude de la formulation et du procédé de fabrication d'éléments de construction en béton de chanvre," PhD dissertation in Civil Engineering, Université de Bretagne-SUD, 2010.

[53] H. Danso, D. B. Martinson, M. Ali, and J. Williams, "Effect of fibre aspect ratio on mechanical properties of soil building blocks," Constr. Build. Mater., vol. 83, pp. 314319, May 2015.

[54] H. Binici, O. Aksogan, M. N. Bodur, E. Akca, and S. Kapur, "Thermal isolation and mechanical properties of fibre reinforced mud bricks as wall materials," Constr. Build. Mater., vol. 21, no. 4, pp. 901-906, 2007.

[55] M. Bouasker, N. Belayachi, D. Hoxha, and M. Al-Mukhtar, "Physical characterization of natural straw fibers as aggregates for construction materials applications," Materials, vol. 7, no. 4, pp. 3034-3048, Apr. 2014.

[56] B. Belhadj, M. Bederina, Z. Makhloufi, A. Goullieux, and M. Quéneudec, "Study of the thermal performances of an exterior wall of barley straw sand concrete in an arid environment," Energy Build., vol. 87, pp. 166-175, Jan. 2015.

[57] T. Verdier, C. Magniont, and G. Escadeillas, "Valorisation de granulats végétaux dans un matériau de construction à matrice minérale," presented at the Colloque International Francophone NoMaD, Toulouse, France, 2012.

[58] Eurocob, Corn cob products, "Product specifications, EU-GRITS 8/10.” 2003.

[59] S. Goodhew and R. Griffiths, "Sustainable earth walls to meet the building regulations," Energy Build., vol. 37, no. 5, pp. 451-459, May 2005.

[60] D. Maskell et al., "Properties of bio-based insulation materials and their potential impact on indoor air quality," presented at the First International Conference on Bio-based Building Materials, Clermont-Ferrand, France, 2015. 
[61] D. Molle and P.-M. Patry, RT 2012 et RT Existant: réglementation thermique et efficacité énergétique. Editions Eyrolles, 2011.

[62] H. Bal, Y. Jannot, N. Quenette, A. Chenu, and S. Gaye, "Water content dependence of the porosity, density and thermal capacity of laterite based bricks with millet waste additive," Constr. Build. Mater., vol. 31, pp. 144-150, 2012.

[63] M. Segetin, K. Jayaraman, and X. Xu, "Harakeke reinforcement of soil-cement building materials: Manufacturability and properties," Build. Environ., vol. 42, no. 8, pp. 30663079, Aug. 2007.

[64] W. . Banks, "Water uptake by scots pine sapwood, and its restriction by the use of water repellents," Wood Sci. Technol., vol. 7, pp. 271-284, 1973.

[65] C. Groot and J. Larbi, "The influence of water flow (reversal) on bond strength development in young masonry," Heron, vol. 44, no. 2, 1999.

[66] H. M. Algin and P. Turgut, "Cotton and limestone powder wastes as brick material," Constr. Build. Mater., vol. 22, no. 6, pp. 1074-1080, Jun. 2008.

[67] A. Mohanty, M. Misra, and L. Drzal, Natural Fibers, Biopolymers, and Biocomposites, CRC Press. 2005.

[68] S. V. Vassilev, D. Baxter, L. K. Andersen, C. G. Vassileva, and T. J. Morgan, "An overview of the organic and inorganic phase composition of biomass," Fuel, vol. 94, pp. 1-33, Apr. 2012.

[69] D. Mohnen, "Pectin structure and biosynthesis," Curr. Opin. Plant Biol., vol. 11, no. 3, pp. 266-277, Jun. 2008.

[70] Y. Diquélou, E. Gourlay, L. Arnaud, and B. Kurek, "Impact of hemp shiv on cement setting and hardening: Influence of the extracted components from the aggregates and study of the interfaces with the inorganic matrix," Cem. Concr. Compos., vol. 55, pp. 112-121, Jan. 2015.

[71] D. Sedan, C. Pagnoux, A. Smith, and T. Chotard, "Mechanical properties of hemp fibre reinforced cement: Influence of the fibre/matrix interaction," J. Eur. Ceram. Soc., vol. 28, no. 1, pp. 183-192, 2008.

[72] F. Jorge, C. Pereira, and J. Ferrera, "Wood-cement composites: a review," Holz Roh Werkst, no. 62, pp. 370-377, 2008.

[73] B. Na, Z. Wang, H. Wang, and X. Lu, "Wood-cement compatibility review," Wood Res., vol. 5, no. 59, pp. 813-826, 2014.

[74] A. Govin, A. Peschard, and R. Guyonnet, "Modification of cement hydration at early ages by natural and heated wood," Cem. Concr. Compos., vol. 28, no. 1, pp. 12-20, Jan. 2006. 
[75] G. Vaickelionis and R. Vaickelioniene, "Cement hydration in the presence of wood extractives and pozzolan mineral additives," Ceram. - Silik., vol. 2, no. 50, pp. 115-122, 2006.

[76] M. Irle and H. Simpson, "Agricultural residues for cement-bonded composites," presented at the Moslemi A (ed) Inorganic-Bonded Wood and Fiber Composite Material Conference Proceedings, 1996, vol. 5, pp. 54-58.

[77] E. Eusebio and M. Suzuki, "Production and properties of plant materials cement bonded composites," Bull. Exp. For. Lab. Tokyo Univ. Agric. Technol., p. 27, 1990.

[78] P. Soroushian, F. Aouadi, H. Chowdhury, A. Nossoni, and G. Sarwar, "Cement-bonded straw board subjected to accelerated processing," Cem. Concr. Compos., vol. 26, no. 7 , pp. 797-802, Oct. 2004.

[79] L. K. Aggarwal, S. P. Agrawal, P. C. Thapliyal, and S. R. Karade, "Cement-bonded composite boards with arhar stalks," Cem. Concr. Compos., vol. 30, no. 1, pp. 44-51, Jan. 2008.

[80] K. Bilba, M.-A. Arsene, and A. Ouensanga, "Sugar cane bagasse fibre reinforced cement composites. Part I. Influence of the botanical components of bagasse on the setting of bagasse/cement composite," Cem. Concr. Compos., vol. 25, no. 1, pp. 91-96, Jan. 2003.

[81] G. A. M. Brasileiro, J. A. R. Vieira, and L. S. Barreto, "Use of coir pith particles in composites with Portland cement," J. Environ. Manage., vol. 131, pp. 228-238, Dec. 2013.

[82] P. Boustingorry, P. Grosseau, R. Guyonnet, and B. Guilhot, "The influence of wood aqueous extractives on the hydration kinetics of plaster," Cem. Concr. Res., vol. 35, no. 11, pp. 2081-2086, Nov. 2005.

[83] M. Ardanuy, J. Claramunt, and R. D. Toledo Filho, "Cellulosic fiber reinforced cementbased composites: A review of recent research," Constr. Build. Mater., vol. 79, pp. 115128, Mar. 2015.

[84] G. Balčiūnas, S. Vèjelis, S. Vaitkus, and A. Kairytè, "Modern building materials, structures and techniques physical properties and structure of composite made by using hemp hurds and different binding materials," Procedia Eng., vol. 57, pp. 159-166, 2013.

[85] J. X. Sun, F. Xu, X. F. Sun, B. Xiao, and R. C. Sun, "Physico-chemical and thermal characterization of cellulose from barley straw," Polym. Degrad. Stab., vol. 88, no. 3, pp. 521-531, Jun. 2005.

[86] Z. Zhu, S. S. Toor, L. Rosendahl, D. Yu, and G. Chen, "Influence of alkali catalyst on product yield and properties via hydrothermal liquefaction of barley straw," Energy, vol. 80, pp. 284-292, Feb. 2015.

[87] La chanvrière de l'Aube, "Kanabat, technical document." . 
[88] B. De Groot, "Alkaline hemp woody core pulping - impregnation characteristics, kinetic modelling and papermaking qualities," 1994.

[89] Y. Hustache and L. Arnaud, "Synthèse des connaissances sur les bétons et mortiers de chanvre." Fibres Recherche Développement, Lhoist, Construire en Chanvre, 2008.

[90] C. Garcia-Jaldon and D. Dupeyre, "Fibres from semi-retted hemp bundles by steam explosion treatment," Biomass Bioenergy, vol. 14, no. 3, pp. 251-260, Mar. 1998.

[91] M. R. Vignon, D. Dupeyre, and C. Garcia-Jaldon, "IEA Network-Biotechnology for the conversion of lignocellulosics morphological characterization of steam-exploded hemp fibers and their utilization in polypropylene-based composites," Bioresour. Technol., vol. 58, no. 2, pp. 203-215, Nov. 1996.

[92] S. Gandolfi, G. Ottolina, S. Riva, G. P. Fantoni, and I. Patel, "Complete chemical analysis of carmagnola hemp hurds and structural features of its components," BioResources, vol. 8, no. 2, pp. 2641-2656, Apr. 2013.

[93] P. Velmurugan et al., "Monascus pigment production by solid-state fermentation with corn cob substrate," J. Biosci. Bioeng., vol. 112, no. 6, pp. 590-594, Dec. 2011.

[94] Y. Millogo, J.-E. Aubert, E. Hamard, and J.-C. Morel, "How properties of kenaf fibers from Burkina Faso contribute to the reinforcement of earth blocks," Materials, vol. 8, no. 5, pp. 2332-2345, 2015.

[95] V. A. Alvarez and A. Vázquez, "Influence of fiber chemical modification procedure on the mechanical properties and water absorption of MaterBi-Y/sisal fiber composites," Compos. Part Appl. Sci. Manuf., vol. 37, no. 10, pp. 1672-1680, Oct. 2006.

[96] H.-R. Kymäläinen and A.-M. Sjöberg, "Flax and hemp fibres as raw materials for thermal insulations," Build. Environ., vol. 43, no. 7, pp. 1261-1269, Jul. 2008.

[97] F. Collet, M. Bart, L. Serres, and J. Miriel, "Porous structure and water vapour sorption of hemp-based materials," Constr. Build. Mater., vol. 22, no. 6, pp. 1271-1280, Jun. 2008.

[98] C. A. S. Hill, A. Norton, and G. Newman, "The water vapor sorption behavior of natural fibers," J. Appl. Polym. Sci., vol. 112, no. 3, pp. 1524-1537, 2009.

[99] M. Maddison, T. Mauring, K. Kirsimäe, and Ü. Mander, "The humidity buffer capacity of clay-sand plaster filled with phytomass from treatment wetlands," Build. Environ., vol. 44, no. 9, pp. 1864-1868, Sep. 2009.

[100]T. Ashour, H. Georg, and W. Wu, "An experimental investigation on equilibrium moisture content of earth plaster with natural reinforcement fibres for straw bale buildings," Appl. Therm. Eng., vol. 31, no. 2-3, pp. 293-303, Feb. 2011.

[101]R. Černý, A. Kunca, V. Tydlitát, J. Drchalová, and P. Rovnaníková, "Effect of pozzolanic admixtures on mechanical, thermal and hygric properties of lime plasters," Constr. Build. Mater., vol. 20, no. 10, pp. 849-857, Dec. 2006. 
971 